\title{
O IMPACTO DA GESTÃO AMBIENTAL NA ADMINISTRAÇÃO DE EMPRESAS SOB A ÓTICA DOS ATORES ENVOLVIDOS: Um estudo de caso no setor de shopping centers
}

Adriano Torres Ribeiro de Castro 


\title{
O IMPACTO DA GESTÃO AMBIENTAL NA ADMINISTRAÇÃO DE EMPRESAS SOB A ÓTICA DOS ATORES ENVOLVIDOS: Um estudo de caso no setor de shopping centers
}

\section{Adriano Torres Ribeiro de Castro}

\author{
Professor Orientador:
}

\section{Antônio Nascimento Júnior - Mestre em Administração}

"Trabalho apresentado em cumprimento às exigências acadêmicas parciais da disciplina Estágio Supervisionado em administração para a obtenção do grau de Administrador" 
Castro, Adriano Torres Ribeiro de.

O impacto da gestão ambiental na administração de empresas sob a ótica dos atores envolvidos: Um estudo de caso no setor de shopping centers - Brasília, 2009.

xii, $71 \mathrm{f}$ : : il.

Monografia (especialização) - Universidade de Brasília, Departamento de Administração, 2009.

Orientador: Antônio Nascimento Júnior, Mestre.

1. Gestão Ambiental. 2. Administração. 3. Shopping Center. I. Castro, Adriano. II. Júnior, Antônio. III. Título. 
Universidade de Brasília

Faculdade de Economia, Administração, Contabilidade e Ciências da Informação e Documentação

DEPARTAMENTO DE ADMINISTRAÇÃO

\title{
O IMPACTO DA GESTÃO AMBIENTAL NA ADMINISTRAÇÃO DE EMPRESAS SOB A ÓTICA DOS ATORES ENVOLVIDOS: Um estudo de caso no setor de shopping centers
}

\begin{abstract}
A Comissão Examinadora, abaixo identificada, aprova o Trabalho de Conclusão do Curso de Administração da Universidade de Brasília do aluno
\end{abstract}

\section{Adriano Torres Ribeiro de Castro}

\author{
Antônio Nascimento Júnior, Mestre em \\ Administração \\ Professor-Orientador
}

\author{
Domingos Sávio Spezia, Mestre em \\ Administração \\ Professor-Examinador
}


Dedico este trabalho a Deus e a minha família que sempre me apoiou em todas as minhas decisões e atividades, através dos quais aprendi a ter uma grande fonte de motivação e inspiração. 
Agradeço ao professor Antônio Júnior pela orientação prestada junto a meu projeto de monografia sem a qual não teria obtido tanto sucesso e satisfação. Além disso, fico também muito grato a toda colaboração fornecida pela administração do shopping Pátio Brasil, se mostrando sempre disposta a ajudar e contribuindo significativamente para a realização deste trabalho. 


\section{RESUMO}

O presente estudo analisou, através da análise do setor de shopping centers, a identificação de fatores que impactam na administração de uma empresa que adota uma postura voltada a realização de seus processos de trabalho em conformidade com os padrões sociais e ambientais. A análise se deu através da coleta de dados com três grupos envolvidos nas ações ambientais, os gerentes de lojas, os gestores administrativos do shopping e os funcionários de apoio. Os dois primeiros grupos foram abordados através de entrevistas pessoais com questionários estruturados e o terceiro grupo através do método de observação. No setor analisado, verifica-se o quanto o envolvimento e comprometimento são cruciais para o sucesso das estratégias definidas, assim como a educação dos agentes é um dos pontos cruciais para que se alcance a cooperação efetiva dos mesmos. Como observação, vale ainda ressaltar que a empresa sob análise possui certa peculiaridade de ser uma filial administrativa e de ter suas políticas orientadas por uma matriz estrangeira, e por isso os próprios fatores que motivaram a organização a adotar a gestão ambiental como parte de sua estratégia ficaram restritos.

1. Gestão Ambiental

4. Responsabilidade

Social Empresarial
2. Shopping Center

5. Desenvolvimento

Sustentável
3. Administração 


\section{SUMÁRIO}

1. INTRODUÇÃO

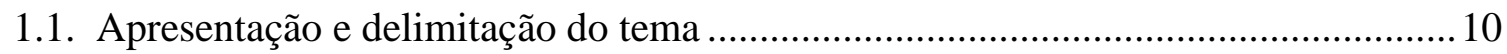

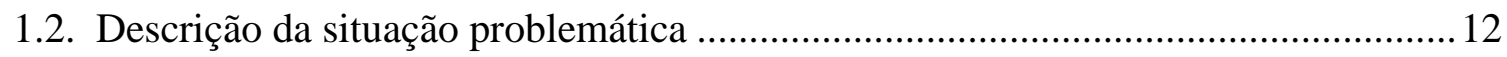

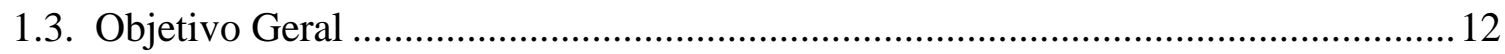

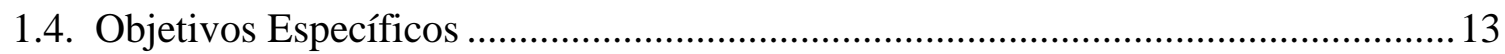

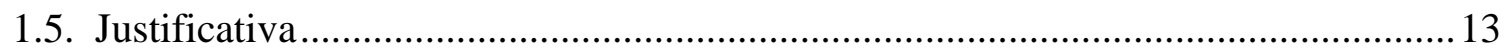

1.6. Metodologia (Métodos e Técnicas de Pesquisa): ...................................................... 14

1.7. Estrutura da Monografia .................................................................................... 14

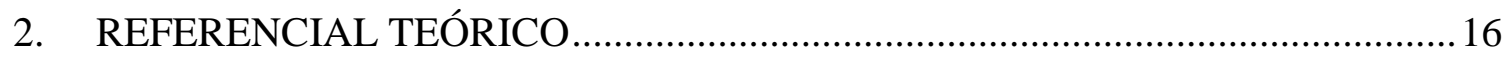

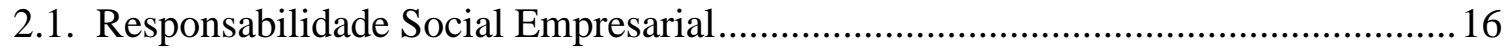

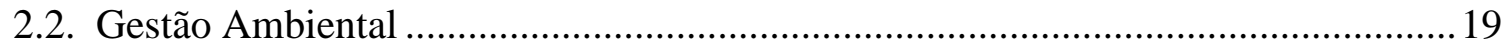

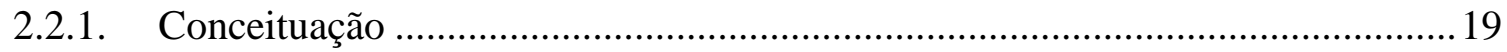

2.2.2. Benefícios da Gestão Ambiental ...................................................................21

2.2.3. A Gestão Ambiental e a interação com seus stakeholders .....................................23

2.2.4. A estrutura organizacional frente a Gestão Ambiental.........................................24

2.2.5. Habilidades necessárias a um Gestor Ambiental................................................2

2.2.6. Sistema de Gestão Ambiental........................................................................26

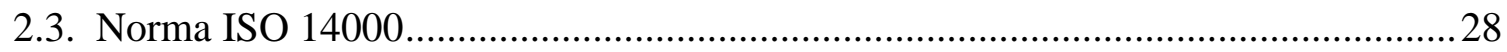

2.4. Desenvolvimento Sustentável.............................................................................

2.5. O shopping Pátio Brasil......................................................................................

2.6. Grupo Sonae Sierra: Grupo administrador do shopping Pátio Brasil.........................35

3. MÉTODOS E TÉCNICAS DE PESQUISA ……….......................................... 41

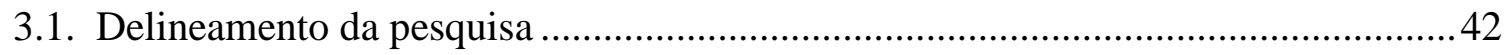

3.2. Descrição das variáveis de pesquisa ......................................................................42

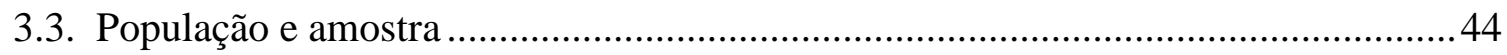

3.4. Procedimentos e instrumentos utilizados na coleta e análise dos dados ....................45

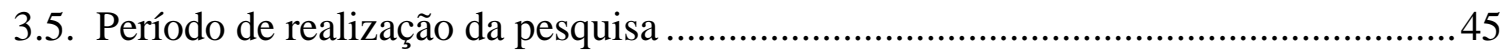

3.6. Comentários sobre o processo da coleta de dados......................................................4

4. APRESENTAÇÃO E ANÁLISE DOS RESULTADOS DA PESQUISA ................46

4.1. Agrupamento, ordenação e descrição dos dados coletados ..........................................46

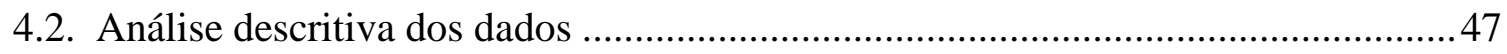

4.2.1. Análise geral do setor de shopping centers no Brasil........................................4

4.2.2. Organização da estrutura Física...........................................................................4 49 


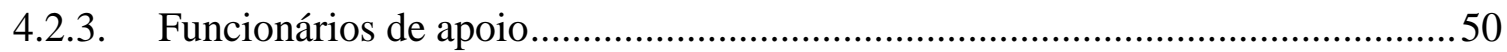

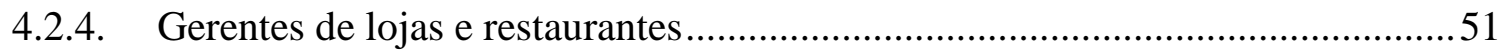

4.2.5. Gestores administrativos do Shopping Pátio Brasil .........................................52

4.3. Uso de tabelas e gráficos ou, ainda, estatísticas .......................................................54

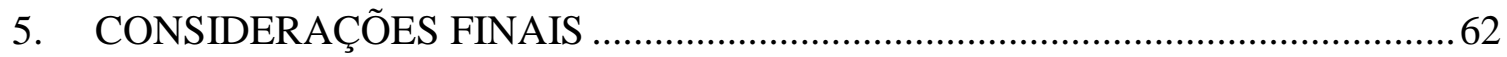

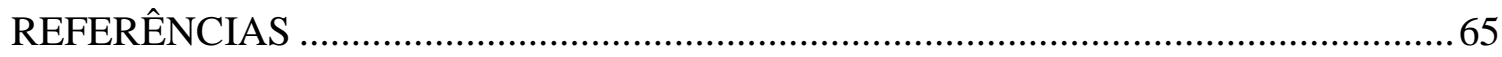

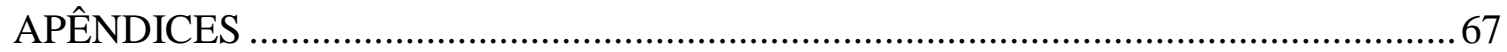

Apêndice A: Questionário - Gerentes das lojas ............................................................67

Apêndice B: Questionário - Gestores Administrativos..................................................69

Apêndice C: Roteiro - Funcionários de apoio ............................................................ 71 


\section{LISTA DE ILUSTRAÇÕES}

Figura 1: Organograma da administração do shopping Pátio Brasil.................................35

Figura 2: Sistemas de gestão ambiental - Grupo Sonae Sierra....................................... 36

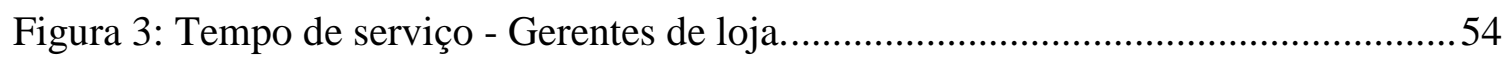

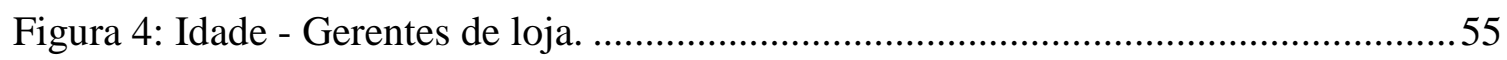

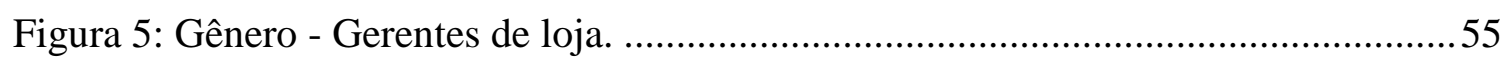

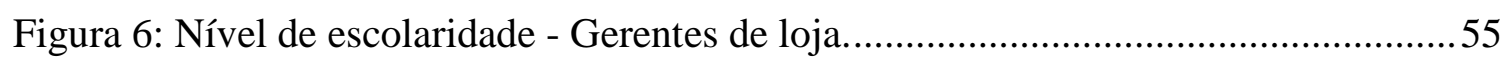

Figura 7: Grau de conhecimento acerca do tema Gestão Ambiental - Gerentes de loja..56

Figura 8: Já realizou algum treinamento acerca do tema Gestão Ambiental? - Gerentes

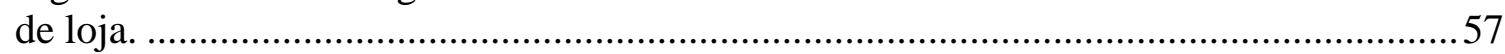

Figura 9: Grau de importância do tema gestão ambiental como obtenção de vantagem

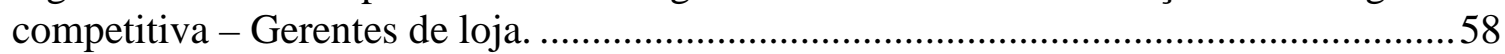

Figura 10: Comunicação dos Programas Ambientais - Gerentes de loja. ........................58

Figura 11: Grau de conhecimento acerca dos programas ambientais realizados pelo

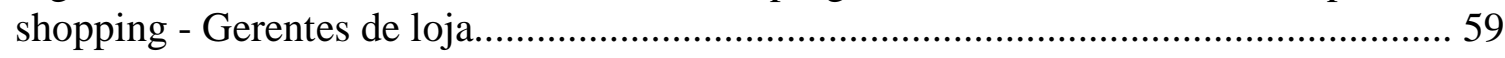

Figura 12: Grau de impacto dos programas ambientais sobre as atividades desenvolvidas

- Gerentes de loja. 60 


\section{LISTA DE TABELAS}

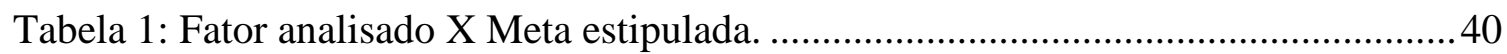

Tabela 2: Grandes números: Brasil em Janeiro de 2009. .............................................. 48

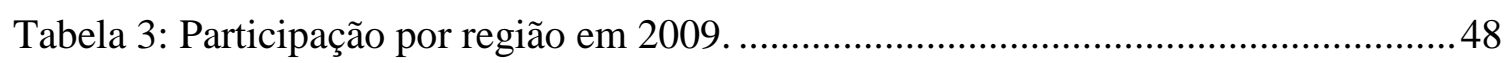

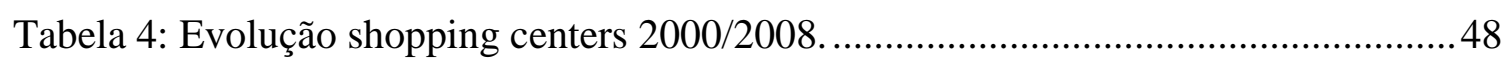

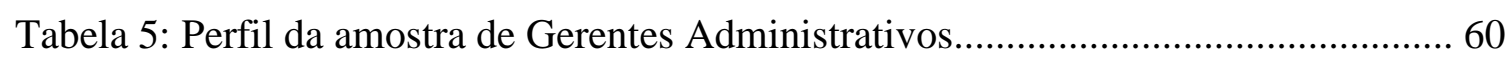

Tabela 6: Benefícios alcançados com os programas ambientais - Gerentes

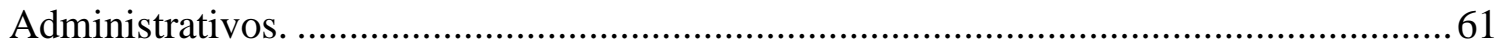




\section{INTRODUÇÃO}

\subsection{Apresentação e delimitação do tema}

Há alguns anos já se vem estabelecendo um novo cenário no mundo dos negócios, onde as empresas passam de instituições com fins apenas econômicos para agentes de negócios com responsabilidades sociais. Esta mudança de filosofia surgiu por volta dos anos 60, 70 e tem ganho uma maior atenção nas últimas décadas, principalmente pela influência dos grupos que se formaram acerca deste pensamento e que vêm procurando aumentar a regulamentação e a importância deste ponto de vista sobre as organizações.

Durante vários séculos, o crescimento das empresas foi sustentado com base em um estilo de produção predatória e que tinha como diretrizes apenas a maximização dos lucros e redução dos custos, não importando muito a forma pela qual iria conseguir concretizar estes objetivos. Dessa forma, o respeito à dignidade humana foi anulada por longos períodos, além da degradação do ambiente, através da extração desplanejada de recursos naturais e do descarte de resíduos originados do processo de produção e mesmo utilização dos produtos e serviços.

Após análises da situação presente e realização de projeções futuras sobre o cenário do planeta, foi percebido que se não houvesse mudanças significativas na forma como as organizações estavam sendo conduzidas, os impactos causados seriam tão graves que os recursos seriam insuficientes para atender às demandas, ou mesmo, o planeta viria a ter falta de recursos naturais essenciais que tornaria a vida na Terra inóspita. Apoiando-se nestas idéias que foram desenvolvidos os temas como: Responsabilidade Social Empresarial, Gestão Ambiental e Desenvolvimento Sustentável.

Estes temas foram criados a partir da idéia de que as empresas deveriam mudar a sua forma de gestão e incluir em seus planos estratégicos, ações de ordem social e ecológica, respeitando dessa forma o ser humano e o meio ambiente. Pode-se ainda considerar que a disseminação destes assuntos na última década obteve uma velocidade muito grande devido a alguns fatores mencionados por Donaire (1999) como: o aumento do nível educacional das pessoas, passando a refletir melhor sobre as variáveis impactantes em suas condições de vida, assim como o desenvolvimento dos meios de comunicação, a 
influência de grupos na sociedade e o próprio governo, principalmente através de regulamentações.

Nesse contexto, ainda se pode dizer que o tema ganhou força, principalmente, quando os governos e empresas passaram a entender estas questões não mais como barreiras ao desenvolvimento econômico, mas como fatores essenciais a obtenção de vantagens futuras.

Abordando especificamente os países em desenvolvimento, se deve considerar que estes possuem uma série de vantagens com relação aos países desenvolvidos neste novo cenário estabelecido. Atualmente, a maior concentração de fonte de recursos naturais se encontra nestes países em desenvolvimento e partir desde ponto já se sabe que a detenção dos recursos sempre foi um dos fatores primordiais a obtenção de vantagem competitiva frente aos concorrentes, cabendo ao governo adaptar a regulamentação visando à perpetuação desta vantagem (DONAIRE, 1999).

Todos os segmentos podem ser considerados como agentes deste cenário, havendo um maior impacto devido ao fim de suas atividades e a intensidade de atuação, tendo inicialmente os setores industriais como o foco de atenção, mas atualmente tendo esta visão sendo disseminada para todos os campos de atuação, principalmente aqueles que estão em contato direto com o cliente. Com isso, os gestores das empresas têm procurado se adaptar cada vez mais as exigências legais e de seus consumidores quanto à linha de pensamento social e ambiental. Dentre estes setores, podemos considerar o de shopping centers, este responsável por um percentual representativo do setor de varejos de muitos países como o do Brasil, representando quase $20 \%$ das transações realizadas (ABRASCE, 2009).

Ainda sobre o setor de shopping centers, deve-se considerar que este abrange um fluxo de serviços tamanho que termina por impactar diversos setores da economia, além da utilização extensiva de alguns recursos, pois não podemos considerar apenas a utilização destes meios em seu espaço físico propriamente dito, mas o impacto causado desde a sua construção até os resultados de se funcionamento, como os fatores utilizados para o abastecimento das lojas, manutenção, eliminação de resíduos, utilização de energia e água, entre outros. Desta forma a responsabilidade da gestão destes empreendimentos se 
torna de tal grandeza frente aos aspectos sociais e ambientais, carecendo de uma maior análise e monitoramento deste setor junto aos aspectos levantados.

\subsection{Descrição da situação problemática}

Partindo da linha de pensamento que orienta as conceituações de Responsabilidade Social Empresarial, Gestão Ambiental e Desenvolvimento Sustentável e que termina por causar um grande impacto em todos os setores da economia, considerou-se importante analisar o segmento de shopping centers, devido ao seu grande potencial de crescimento e pelo impacto direto e indireto causado a seus agentes.

Levando em consideração as especificidades do setor de shopping centers e de seu impacto na abordagem ambiental, se visa com este estudo analisar sob a ótica dos atores envolvidos no setor de shopping centers, quais fatores influenciam a prática da Gestão Ambiental em suas organizações.

Visto que o setor analisado é composto por empresas que não possuem impactos considerados muitas vezes de forma direta ao meio ambiente, com uma estrutura organizacional mais simplificada e com foco em alguns setores administrativos, se procurará descobrir sob a ótica destes gestores: como a integração da gestão ambiental vem impactando a sua forma de gerir a organização.

Considerando a empresa sob análise, deve-se considerar que esta é uma filial administrativa, onde as diretrizes principais de gerenciamento da empresa são originadas do escritório matriz situado em Portugal. Desta forma, ainda neste estudo poderá ser percebido como é o entendimento e o impacto dos objetivos gerais e seu desdobramento para metas específicas segundo o tema da gestão ambiental.

Devido a pequena quantidade de empresas deste segmento que possuem ações estruturadas junto ao tema, este estudo procurou analisar somente a empresa considerada como destaque no cenário de Brasília ante a programas de gestão ambiental.

\subsection{Objetivo Geral}

Este estudo tem como objetivo geral, identificar através da percepção do atores envolvidos com os programas ambientais do shopping Pátio Brasil, os fatores que impactam o desenvolvimento das ações relacionadas ao tema. 


\subsection{Objetivos Específicos}

Tendo em vista a dimensão de análise do objetivo geral proposto, se faz necessário o desdobramento deste em alguns objetivos específicos:

- Analisar o contexto atual dos temas: Responsabilidade Social Empresarial, Gestão Ambiental e Desenvolvimento Sustentável;

- Verificar como os gestores, gerentes de lojas e funcionários operacionais percebem o impacto das metas ambientais na execução de suas atividades;

- Comparar a percepção dos agentes analisados acerca das ações ambientais;

- Verificar como estas metas ambientais são repassadas ao público alvo da pesquisa;

- Identificar o impacto das diretrizes ambientais formuladas em uma empresa matriz sobre uma unidade filial; e,

- Levantar práticas de gestão ambiental que possam orientar outras empresas do setor a desenvolverem ações ambientais corretas.

\subsection{Justificativa}

A constante mudança no cenário de negócios termina por obrigar as empresas a buscarem constantemente oportunidades que lhes dêem alguma vantagem competitiva sobre seus concorrentes, e na situação atual, empresas que desenvolvam planos que adaptem seus fluxos de produção às questões ambientais, se prevenirão de problemas futuros com a legislação e com degradação de sua imagem ante a sociedade.

A mudança de consciência que vêm acontecendo na sociedade somente foi possível devido a forças de grupos que viram a importância do tema junto as organizações e a estudos como estes que procuram mostrar os benefícios de se adotar medidas conscientes junto ao meio ambiente, podendo dessa forma até gerar economias de custos a empresa.

Outro fator importante, é que a utilização de estratégias com foco ambiental motiva as organizações a introduzirem-se no segmento "verde" atendendo a um nicho muitas vezes não explorado por seus concorrentes e como conseqüência a aquisição de vantagem competitiva. 
As empresas que não se adaptarem a essa nova situação estarão certamente comprometendo o futuro de suas organizações.

\subsection{Metodologia (Métodos e Técnicas de Pesquisa):}

Devido às características dos indivíduos sob análise, como quantidade de elementos na população, melhor momento e local para encontrá-los, assim como informações já disponíveis sobre o assunto, concluiu-se que a pesquisa fosse de caráter descritivo, objetivando explicitar as peculiaridades do fenômeno que está sendo estudado (VIEIRA, 2002). Visto a situação no qual se encontra os elementos a serem analisados, foram escolhidos os métodos de observação e questionário como procedimentos de coleta de dados, sendo que este último realizado através de entrevista ou distribuição pessoal (COLLIS et alli, 2005).

Neste estudo, três grupos estão sendo analisados: os gerentes das lojas do shopping, os gestores administrativos e os funcionários de apoio, assim como a estrutura física, como ponto complementar a pesquisa.

Para análise dos dois primeiros grupos foram utilizados questionários previamente estruturados com questões fechadas, de múltipla escolha, escala likert e uma questão aberta para coleta de sugestões. Devido ao caráter da amostra, o procedimento de coleta foi feito através da entrevista pessoal e da distribuição individual, método sendo escolhido em favor da disponibilidade do entrevistado (COLLIS et alli, 2005). Os questionários para ambos os grupos possuem algumas perguntas semelhantes para coletar informações acerca da mesma situação e dessa forma gerar comparação de percepção entre os dois grupos.

O terceiro grupo avaliado, o dos funcionários de apoio foi verificado através do procedimento de observação, se utilizando o pesquisador de um roteiro semi-estruturado, com tópicos relevantes a serem pesquisados sobre o grupo. Este método foi escolhido visto os objetivos da pesquisa, procurando avaliar estes elementos em seu ambiente de trabalho, sem a interferência direta do pesquisador e através disto poder coletar acertos e erros de procedimentos na execução de suas atividades (COLLIS et alli, 2005).

\subsection{Estrutura da Monografia}

Este trabalho de monografia está estruturado em cinco capítulos, sendo que o primeiro é o que se encontra este tópico, tendo como foco a introdução acerca do trabalho, 
apresentando as idéias principais de fundamentação à pesquisa, como os objetivos, justificativas e métodos a serem utilizados.

O capítulo dois tem como objetivo dar uma sustentação teórica aos temas abordados pelo estudo, tendo neste trabalho a utilização de conhecimentos acerca da Responsabilidade Social Empresarial, Gestão Ambiental, ISO 14000 e Desenvolvimento Sustentável. Além disso, é apresentada uma breve análise acerca da empresa utilizada como estudo de caso pela pesquisa.

Para um maior delineamento sobre o procedimento de pesquisa a ser utilizado, assim como a caracterização da amostra, a descrição das variáveis de pesquisa e o período no qual foi realizada a coleta de dados, o capítulo três, denominado métodos e técnicas de pesquisa, discorre sobre estes assuntos de maneira detalhada.

Visando a explicitação dos dados obtidos com a pesquisa, o capítulo quatro é organizado através de tópicos, em que cada um é retratado a situação atual dos grupos e setor analisado. Primeiramente são feitas análise descritivas das informações obtidas, para no último tópico deste capítulo ser feita uma apresentação dos dados através de gráficos e tabelas, mostrando maiores detalhes sobre a amostra obtida assim como dados específicos sobre o estudo.

Por fim, no capítulo cinco é apresentada a conclusão sobre o trabalho, procurando mostrar principalmente a ligação entre os dados apresentados no capítulo quatro e os objetivos iniciais do estudo mostrados no capítulo um. Ao mesmo tempo, são apresentadas idéias e sugestões para melhorias dos programas utilizados por empresas do setor de shopping centers. 


\section{REFERENCIAL TEÓRICO}

Por muitos anos as empresas de maneira geral mantinham seu foco apenas na geração de novos produtos a um custo cada vez menor, para que conseqüentemente obtenham um lucro maior. Este pensamento veio acompanhando os administradores de empresas ao longo dos séculos sem haver preocupações maiores com seu público interno, externo e as conseqüências de suas ações ao longo do fluxo de produção. Visão esta que começou a ser mudada bem recentemente quando a pressão sobre estes dirigentes aumentou, vindo por parte de seus próprios funcionários, consumidores e comunidades impactadas por suas ações.

\subsection{Responsabilidade Social Empresarial}

O conceito de Responsabilidade Social Empresarial trouxe para as organizações a idéia de o quanto é crucial para o seu crescimento, alinhar o planejamento de ações com o fortalecimento do relacionamento com seus stakeholders. Isto se justifica, pois este fortalecimento não somente influencia na conquista de novos clientes como melhora a imagem da empresa perante a sociedade.

Segundo o guia elaborado pelo Instituto Ethos (2003) sobre a relação entre as microempresas e a RSE, este conceito tem seu surgimento e aumento de sua importância segundo três fatores:

- A revolução tecnológica que vem acontecendo, principalmente nos meios de comunicação, e tendo como resultado a redução das distâncias e aumento da capacidade de proliferação de informações;

- A revolução educacional, relativa ao número de pessoas que vêem buscando se capacitar através da escola e conseqüentemente a busca pela informação;

- A revolução cívica, que é ligada a forma de organização de grupos cada vez mais freqüente em pró de seus direitos, como por exemplo, as ONGs que lutam pela preservação do meio ambiente ou por maiores benefícios ao assistencialismo da população. 
O patamar no qual uma empresa pode se enquadrar a respeito da responsabilidade social empresarial vai depender diretamente de dois pilares - a ética e a transparência - que suas ações possuem. Tendo a ética como os valores que guiam as ações da empresa, ou seja, se estes estão de acordo com as leis e princípios de seus stakeholders. Já a transparência se faz valer a partir da demonstração de que as atividades da empresa estão corretas e disponíveis a sociedade. Para que estes pilares sejam efetivos o Instituto Ethos (2003) sugere uma lista com sete diretrizes básicas para que a RSE seja implantada:

1. Adote valores e trabalhe com transparência;

2. Valorize empregados e trabalhadores;

3. Faça sempre mais pelo meio ambiente;

4. Envolva parceiros e fornecedores;

5. Proteja clientes e consumidores;

6. Promova sua comunidade;

7. Comprometa-se com o bem comum.

Ressaltando que o foco deste estudo vem em consonância principalmente com os valores acerca do meio ambiente, e com isso, a diretriz número três se torna a mais importante a analisar. Tendo esta diretriz como prioridade para a redução do desperdício de recursos naturais e o impacto que suas ações têm sobre o meio ambiente, como por exemplo, a coleta seletiva, redução no consumo de água, o barulho que o empreendimento causa no local de atuação.

Para que esta diretriz se faça eficaz, são enumeradas algumas ações que podem contribuir para o alcance dos resultados esperados e que podem ser agrupadas em alguns fatores macro, como: estabelecer políticas de operações que incentivem os funcionários a agirem de acordo com as leis ambientais e que sejam motivados a desenvolverem ações visando o "verde". Criação de ações que visem a redução de resíduos, como a própria reciclagem, além da prevenção da poluição, optando por produtos que não sejam tóxicos e o uso eficiente de recursos como a água e a energia. Por último, ainda é importante se lembrar 
dos projetos ecológicos, dando preferência, por exemplo, a fornecedores que atuam de forma consciente com seus impactos ao meio ambiente. (INSTITUTO ETHOS, 2003)

Pode-se considerar, que no Brasil, este movimento rumo à adoção da RSE pelas organizações veio em decorrência da conscientização gerada pelas mudanças políticas, principalmente quando nos referimos as diretas já nos anos 80 e o impeachment do presidente Collor no início dos anos 90. Estes fatos são considerados de grande importância para o tema, pois influenciaram diretamente na percepção da população sobre a questão da ética das organizações e das consequiências das ações destas na sociedade, considerando neste caso, o governo como a "empresa" causadora dos problemas éticos e, falta de transparência.

Além dos acontecimentos políticos mencionados, temos ainda a Conferência Rio 92 e a campanha do sociólogo Hebert de Souza, o Betinho, que incitaram ainda mais as discussões acerca dos impactos ambientais e sociais das empresas. É importante salientar, que a partir destes marcos, que a população foi motivada a se organizar e criar grupos que lutem pelos seus direitos e regulação destes setores, como o Instituto Ethos de Empresas e Responsabilidade Social e demais fóruns para debates, como o Fórum Social Mundial, realizado no Brasil desde 2001.

Como se trata de um tema relativamente novo e que ainda não possui uma literatura bem ampla e difundida, o RSE muitas vezes é confundido com outros assuntos relativos a ações de ordem social, como é o caso da Filantropia. Esse desentendimento do assunto termina por gerar prejuízos a sua abordagem, muitas vezes criando opositores a implementação de ações vinculadas a RSE. O que torna a educação dos agentes envolvidos cada vez mais importante, sinalizando os fundamentos, princípios e conseqüências dos programas, como por exemplo, na comparação que temos com ações filantrópicas, onde este atua de forma a gerar benefícios somente aos clientes externos, enquanto a RSE procura envolver todos os stakeholders envolvidos no processo, desde a aquisição de matéria-prima até o impacto no ambiente onde seu produto será destinado.

Para a aplicação desta ferramenta de gestão, autores como Porter e Kramer (2006) definem que a forma de abordagem do tema na organização irá ser extremamente crucial para o seu sucesso, pois a percepção do mesmo através de uma simples ferramenta de gestão ou de algo que deve ser tratado junto a formação de estratégia, gerará benefícios para a empresa, inclusive como fonte de oportunidades, inovação e vantagem competitiva. 
Apontado como um dos pilares a valorização do meio ambiente, a responsabilidade social empresarial, termina por remeter a outro tema, chamado de gestão ambiental. Este considerado como o pilar teórico para muitos assuntos acerca da responsabilidade que empresas e governos têm sobre o impacto ao meio ambiente, além de ser ele mesmo uma ferramenta teórica fundamental para a definição de estratégias e políticas no momento de adotar ações que visem tornar a empresa ambientalmente correta.

\subsection{Gestão Ambiental}

\subsubsection{Conceituação}

Visto o cenário apresentado, muitas empresas se mostram motivadas a buscar ferramentas que as auxiliem nesta interação entre planejamento e preservação ambiental, e atualmente uma das mais procuradas é a de gestão ambiental, que Meyer (2000 apud KRAEMER, 2004) a apresenta como sendo:

- “objeto de manter o meio ambiente saudável (à medida do possível), para atender as necessidades humanas atuais, sem comprometer o atendimento das necessidades das gerações futuras";

- "meio de atuar sobre as modificações causadas no meio ambiente pelo uso e/ou descarte dos bens e detritos gerados pelas atividades humanas, a partir de um plano de ação viáveis técnica e economicamente, com prioridades perfeitamente definidas";

- "instrumentos de monitoramentos, controles, taxações, imposições, subsídios, divulgação, obras e ações mitigadoras, além de treinamento e conscientização";

- "base de atuação de diagnósticos (cenários) ambientais da área de atuação, a partir de estudos e pesquisas dirigidos em busca de soluções para os problemas que forem detectados." (MEYER, 2000: p. 32)

Temos ainda a definição de Nilsson (1998 apud CORAZZA, 2003) que já introduz o termo gestão ambiental, mostrando como esta interage com seus stakeholders, sendo estes internos e externos:

"Gestão ambiental envolve planejamento, organização, e orienta a empresa a alcançar metas [ambientais] especificas, em uma analogia, por exemplo, com o que ocorre com a gestão de qualidade. Um 
aspecto relevante da gestão ambiental é que sua introdução requer decisões nos níveis mais elevados da administração e, portanto, envia uma clara mensagem à organização de que se trata de um compromisso corporativo. A gestão ambiental pode se tornar também um importante instrumento para as organizações em suas relações com consumidores, o público em geral, companhias de seguro, agências governamentais, etc." (NILSSON, 1998:134).

A partir dos anos 60 se começa a constatar uma nova onda a respeito dos impactos ambientais causados pelas ações das empresas, iniciada por debates decorridos na reunião do Clube de Roma, no fim dos anos 60, para logo após ser fortalecida pela Conferência de Estocolmo sobre Meio Ambiente em 1972 e pelo relatório "Nosso Futuro Comum”, criado pela ONU em 1987. Já no ano de 1985, podemos verificar o inicio da consolidação do pensamento de gestão ambiental em confluência com o planejamento estratégico das organizações, como fortalecimento desta idéia, se tem a reunião de empresas do setor químico, líderes mundiais na ocasião e que firmaram um acordo de "atuação responsável", tendo como objetivo implantar estratégias que diminuam o impacto de suas atividades no meio ambiente (ROSE, 2003).

Apesar da geração destes fatores tão importantes para o movimento acerca da gestão ambiental, o seu impacto maior se deu somente no final dos anos 80 e início dos anos 90, época esta onde países de diversas regiões do mundo começaram a criar leis específicas para este tema, visando reduzir a degradação do meio ambiente através da regulação dos setores industriais e de serviços.

Dois temas que estão relacionados diretamente são a gestão ambiental e o impacto ambiental, sendo a primeira uma ferramenta para se evitar as conseqüências da segunda, e no Brasil, a conceituação do tema se faz a partir do Conselho Nacional do Meio Ambiente (CONAMA) expressa no art. $1^{\circ}$ da Res. 1 , de 23.1.86:

"considera-se impacto ambiental qualquer alteração das propriedades físicas, químicas e biológicas do meio ambiente, causada por qualquer forma de matéria ou energia resultante das atividades humanas, que direta ou indiretamente, afetam-se: a saúde, a segurança e o bem-estar da população; as atividades sociais e econômicas; a biota; as condições estéticas e sanitárias do meio ambiente e a qualidade dos recursos naturais." (CONAMA, 1986: 1)

Dentre estes acontecimentos relatados e que foram de extrema importância para o crescimento do conceito a respeito da gestão ambiental, vale ainda ressaltar a importância da 
"Carta de Roterdã", documento este que foi elaborado pela Câmara Internacional do Comércio (International Chamber of Commerce), e que trata de alguns pontos que atribuem maior importância a gestão ambiental (ROSE, 2003). Estes fatores foram denominados de "Princípios do Desenvolvimento Sustentável", e foram organizados em 16 princípios que servem de parâmetro de avaliação sobre as atividades realizadas pelas empresas. Ainda no final dos anos 90, com o fortalecimento das certificações ISO, a etapa de solidificação da gestão ambiental junto a estratégia foi consolidada, tendo iniciada uma corrida das organizações pela conquista destas certificações devido a própria exigência dos consumidores (DONAIRE, 1999).

Rose (2003) ainda destaca a idéia de que a partir destas mudanças podemos verificar uma postura diferente das empresas em face de seu planejamento de produção, pois antigamente estas realizavam a produção sem se preocupar com as a degradação do meio ambiente, tendo posteriormente que arcar com grandes custos de recuperação da área prejudicada, e isto incentivou uma análise a respeito dos gastos com a prevenção em comparação dos custos com a recuperação, e que na maioria das vezes na primeira situação resultava em investimentos menores.

Donaire (1999) reforça este pensamento de que "algumas empresas, porém, têm demonstrado que é possível ganhar dinheiro e proteger o meio ambiente mesmo não sendo uma organização que atua no chamado 'mercado verde', desde que as empresas possuam certa dose de criatividade e condições internas que possam transformar as restrições e ameaças ambientais em oportunidades de negócios".

\subsubsection{Benefícios da Gestão Ambiental}

Dessa forma se faz importante lembrar que além da implantação desta ferramenta, não coexistindo primeiramente uma mudança na cultura da organização em busca de proliferar a idéia de que estas ações gerarão diversos benefícios à empresa, os resultados traçados não serão alcançados e ocasionará um descontentamento em relação ao programa traçado, muitas vezes, motivando a formação de grupos internos à empresa que tentarão se impuser contra os novos planos.

Com relação aos benefícios desta ferramenta de gestão, North (1997) apresenta o quadro 1 a seguir: 
Benefícios Econômicos:

Economia de custos:

- Economia devido ao consumo reduzido de energia e outros recursos.

- Economia devido a reciclagem, venda de produtos secundários derivados da produção e lixo, resultando na diminuição dos custos com a eliminação.

- Redução das taxas ambientais, multas e penalidades devido a poluição.

Incremento de receita:

- Aumento da contribuição marginal de produtos verdes que são vendidos a preços mais altos.

- Aumento da participação de mercado devido a inovação dos produtos e menor concorrência.

- Produtos completamente novos abrem novos mercados.

- Aumento da demanda por produtos que contribuem para a diminuição da poluição.

Benefícios estratégicos:

- Melhoria da imagem institucional.

- Renovação no portfólio de produtos.

- Aumento da produtividade.

- Maior comprometimento por parte da força de trabalho e melhor relacionamento com os empregados.

- Criatividade e abertura para novos desafios.

- Melhores relações com órgãos públicos, comunidade e grupos ambientalistas.

- Acesso garantido a mercados estrangeiros.

- Melhor adequação aos padrões ambientais.

\section{Quadro 1: Benefícios da Gestão Ambiental para uma empresa.}

Fonte: Adaptado de North, K. Environmental Business Management: An Introduction. 2. ed.

Geneva: International Labour Office, 1997.

North (1997) ainda apresenta alguns argumentos para que as empresas se comprometam com a gestão ambiental e obtenha maiores vantagens destes benefícios apresentados, como adotar estratégias ambientais primeiro que a concorrência, mostrar a seus stakeholders que a empresa realmente leva a sério a questão ambiental, utilizar programas de combate a poluição, além de traçar planos que busquem o maior comprometimento dos funcionários. 
Ainda sobre os benefícios de se aderir a políticas de gestão ambiental, existem autores como Winter (1987 apud DONAIRE, 1999) que mostram razões para que a empresa possua um foco junto à gestão ambiental e colocando a perca de oportunidade que estas terão caso não atuem conforme as ações traçadas, como a ausência de empresas orientadas para o meio ambiente, acarretará em uma economia não voltada para o meio ambiente e não obtendo dessa forma o mínimo para que se tenha uma boa qualidade de vida. Ele ainda coloca que sem a gestão ambiental, a empresa estará perdendo muitas fontes de oportunidades de negócios, além de estar sujeita a graves danos ambientais futuros e que sujeitarão a altos custos para a empresa e responsabilização dos administradores por não terem tomado medidas prévias acerca deste problema. Um ponto interessante que o autor coloca, é ainda a preocupação pelo lado emocional das pessoas envolvidas, levantando a idéia de que ainda haveria um peso na consciência dos envolvidos em problemas ambientais por não agirem da forma mais correta e por estarem causando danos à natureza.

\subsubsection{A Gestão Ambiental e a interação com seus stakeholders}

Buscando ainda mostrar a eficiência da gestão ambiental, mas com um diferente foco de visão, temos a vertente de que a adoção desta atividade exigirá adequações das empresas quanto as novas especificidades da produção e dessa forma demandará novas tecnologias e por consequiência necessidade de uma maior qualificação dos trabalhadores e geração de empregos, o que torna ainda mais interessante a aplicação de estratégias ambientais, visto que este é um problema que vêm se agravando nos últimos anos (CONRADO, 2000).

Em linhas gerais, este grau de envolvimento da empresa com a gestão ambiental vai depender da interação entre os atores internos e externos, e dependendo do setor em que ela atua também haverá um nível de pressão determinado. Segundo Maimom (1994) as empresas gerarão respostas a estas pressões de três maneiras:

- Incorporação de equipamentos para a prevenção da poluição, sem haver mudanças nos processos e produtos.

- Modificação interna de processos e produtos, tentando se adequar as novas exigências.

- Integração entre o planejamento estratégico da empresa e a função ambiental, possuindo dessa forma um comportamento pró-ativo. 
A gestão ambiental ainda pode ser encarada pelas organizações de duas formas, sendo as atitudes das empresas de forma defensiva ou proativa (referente à postura tomada pelas empresas a partir do final dos anos 80 e que se segue até os dias de hoje).

Quando as empresas assumem uma postura mais defensiva, estas vêem as atividades relacionadas à gestão ambiental como sendo algo que não gera nenhuma vantagem, onerando apenas os funcionários em termo de tempo para que monitorem a regulamentação e comparem com as atividades da organização, para que esta não seja penalizada por alguma ação danosa ao meio ambiente ao longo de seu fluxo de produção (DONAIRE, 2003).

Do outro extremo se tem a postura proativa e que leva a empresa a encarar o investimento em gestão ambiental como algo que gerará vantagem competitiva frente a seus concorrentes, tendo como foco a gestão antecipada das ações da empresa, prevenindo-a de maiores problemas futuros além da geração de novas oportunidades de negócio.

\subsubsection{A estrutura organizacional frente a Gestão Ambiental}

Outro ponto de análise bastante importante a se considerar quando se faz uma análise da ferramenta de gestão ambiental é o impacto que esta faz na estrutura da empresa e como é a forma de atuação deste departamento nas organizações.

Pode-se considerar que anteriormente aos anos 1980, o departamento ambiental era bem reduzido e possuía o foco de suas atribuições no acompanhamento das legislações e elaboração de documentos que atestassem como estava sendo o desempenho da empresa ante as questões ambientais.

Já nos anos 80, a estratégia desse departamento começou a se voltar para uma divulgação interna de seus conceitos e conseqüente aproximação dos funcionários de suas atividades, como a elaboração de programas de prevenção e educação dos trabalhadores (CORAZZA, 2003).

A partir do final dos anos 80 se tem uma mudança estratégica na forma de conduzir o departamento, inclusive tendo este uma maior importância em face das decisões de ordem estratégica para a empresa, recebendo responsabilidades como a busca de oportunidades estratégicas e a elaboração de políticas ambientais proativas que serão relevantes da determinação do planejamento da organização, atribui-se grande parte destas mudanças, as relações que as empresas instituíram com os agentes influenciadores, como ONGs, Órgãos do 
governo, outras empresas privadas, e mais recentemente os próprios acionistas que em alguns países já começam a avaliar as empresas com base na sua relação com o meio ambiente (CORAZZA, 2003).

Tratando ainda da forma estrutural com o qual as empresas lidam com a gestão ambiental, Corazza (2003) levanta a idéia de que as organizações podem assumir estas novas responsabilidades de duas formas, sendo estas, pontual ou matricial. A primeira forma de organização é caracterizada pela criação da função e/ou departamento ambiental, tendo estes como conseqüências a centralização da gestão.

Autores como Donaire (1992) e Sanches (2000) ainda atribuem que essa forma de organização é constituída pela maneira na qual a gestão ambiental é percebida pela organização, tendo a cúpula administrativa como a responsável pela percepção de que as variáveis ambientais são impactantes nas políticas organizacionais e somente após a integração destas que haveria uma tentativa de envolvimento dos demais setores da empresa, agindo de cima para baixo segundo a hierarquia.

\subsubsection{Habilidades necessárias a um Gestor Ambiental}

Agindo dessa forma, considera-se que as atividades relacionadas à gestão ambiental estarão ligadas a pessoas que possuem status e prestígio na empresa, e com isso terão um grau de compromisso mais alto por parte dos funcionários. Para estas variáveis impostas, Donaire (1999) acredita que estes gestores devem possuir algumas habilidades específicas e que são listadas da seguinte forma:

- Habilidade técnica: "para poder avaliar as diferentes alternativas, em relação a insumos, processos e produtos, considerando-os sob o aspecto ambiental e seu relacionamento com os conceitos de custos e de tempo". (p. 86)

- Habilidade administrativa: "relacionada com o desempenho das tarefas do processo administrativo: planejar, organizar, dirigir e controlar, pois caberá a ele a responsabilidade de executar a política de meio ambiente ditada pela organização". (p. 86)

- Habilidade política: "para sensibilizar os demais administradores da empresa, que lhe podem dar apoio e respaldo organizacional no engajamento da temática ambiental, 
propagando e consolidando a idéia de que sua atividade, antes de ser uma despesa a mais para a organização, é uma grande oportunidade para a prospecção de novas formas de redução de custos e melhoria de lucros". (p. 87)

- Habilidade de relacionamento humano: "para conseguir a colaboração e o engajamento de todos os funcionários para a causa ambiental da empresa, pois o sucesso desse empreendimento está intimamente ligado à participação coletiva e à incorporação desta variável à cultura da organização". (p. 87)

Abordando a organização estrutural da empresa de forma matricial podemos considerar que esta se difere em grande parte da pontual pela incorporação de novas funções dentro das demais áreas relacionadas, como por exemplo, marketing e recursos humanos, havendo dessa forma a mudança de atividades e rotinas preexistentes.

Buscando alinhar a gestão ambiental com um dos atores que serão analisados neste trabalho, se faz necessária a co-relação entre as atividades de gestão e a gestão ambiental, como no próprio planejamento estratégico, onde Donaire (1999: 05) aborda a atuação deste departamento e que "deverá avaliar o ambiente externo procurando identificar no que diz respeito às questões ecológicas, as oportunidades e os riscos existentes na legislação ambiental, no nível de consciência dos consumidores e da sociedade como um todo, no que está sendo feito pela indústria a que a empresa pertence, no comportamento dos concorrentes e no avanço tecnológico nesse campo". Além de atividades que fornecerão informações para a gestão como as pesquisas de marketing, que gerarão insumos para a área identificando como os produtos atuais estão sendo vistos pelos consumidores em relação a problemática ambiental e se existe algum nicho no qual a empresa poderia se inserir afim de implantar um maior número de produtos verdes e que pudessem dar um maior retorno a organização.

\subsubsection{Sistema de Gestão Ambiental}

Muitas vezes o conceito de Sistema de Gestão Ambiental (SGA) e a própria gestão ambiental se confundem na literatura, isso por conta de serem definidos algumas vezes como uma evolução do outro, como faz Moreira (2001), onde diz que a gestão ambiental pode ser considerada uma empresa que possui o departamento que cuida das questões ambientais, mas que age de forma reativa. Já uma empresa com o SGA, seria uma organização onde encontraríamos uma postura pró-ativa em relação as políticas ambientais, tendo o conceito 
muito bem difundido ao longo de toda a organização, ou seja, ações de prevenção já ligadas a própria cultura da companhia.

Já Almeida et alli (p. 48, 2004) diferencia os dois conceitos colocando a Gestão Ambiental como "a forma pela qual a empresa se mobiliza, interna e externamente, na conquista da qualidade ambiental desejada. Para atingir a meta, ao menor custo, e forma permanente, o SGA é a estratégia indicada”. Dessa forma se tem o objetivo do SGA que é o como a empresa fará para garantir um processo de melhoria contínua ante a questão da gestão ambiental.

Para que o SGA se torne efetivo, se faz necessária a integração de três fatores internos às empresas - os recursos físicos, humanos e financeiros -, além disso, estes devem ser disponibilizados conforme as necessidades, pois tendo a falta de algum, poderá comprometer o sistema (ALMEIDA et alli, 2004). Esta nova variável que será integrada aos mecanismos já existentes na empresa, requer uma análise minuciosa dos recursos já utilizados para que estes estejam em acordo com os novos requisitos. Outro ponto a se considerar e que pode ser decisivo na implementação do SGA, é forma pelo qual este será conduzido na empresa, ou seja, este dependerá em grande parte da motivação e contribuição de todos para que se torne efetivo.

Atualmente uma empresa que não possui um SGA termina tendo conseqüências graves para a gestão de seus negócios e da geração de novas oportunidades, como mostra Moreira (2001):

- Perda de competitividade;

- Multas;

- Acidentes Ambientais;

- Danos à imagem;

- Processos na justiça;

- Paralisações;

- Passivos Ambientais. 
Mesmo tendo a consciência de todos estes pontos negativos, muito empresários ainda se negam a implantação do SGA, justificando em sua maioria que os retornos obtidos com tal investimento não compensam. Estes terminam por implantar a ferramenta somente quando as pressões externas aumentam de tal modo que começa a causar grandes prejuízos à empresa (MOREIRA, 2001).

Estes sistemas de gestão ambiental ainda são controlados por uma série de normas reguladoras, as normas ISO 14001 e ISO 14004, e por causa dessa interligação dos temas, se faz necessário uma breve explicação sobre o funcionamento destas normas originadas da ISO 14000 e que possuem uma orientação técnica voltada para a questão ambiental.

\subsection{Norma ISO 14000}

O aumento crescente da consciência ambiental e a escassez de recursos naturais vêm influenciando cada vez mais as organizações a contribuírem de forma sistematizada na redução dos impactos ambientais associados aos seus processos. A partir dessa consciência formada, que no inicio da década de 90 o Instituto internacional de regulação de normas, ISO, resolveu instituir algumas regras para que as organizações tomassem medidas preventivas quanto à degradação do meio ambiente e fossem certificadas caso estivessem atuando em seu processo de produção de forma eficiente (MOREIRA, 2001). Com isso em 1993 foi formado o Comitê Técnico TC 207 que teria como objetivo desenvolver essas normas nas áreas envolvidas com o meio ambiente. E dentro desse comitê foram formados outros 9 Subcomitês que tinham a responsabilidade de instituir regras sobre uma determinada área da certificação ISO 14000 (MOREIRA, 2001).

Para que a criação dessas normas ganhasse continuidade e também pontos de vistas diferentes, foram instituídas diversas agências, sendo uma em cada país integrante da ISO e que ficaria responsável pela regulação dessas normas em seu território, no Brasil a agência responsável pela criação dessas normas foi a ABNT e pela parte fiscalizadora o Inmetro (VALLE, 2002).

A primeira norma instituída e que serve de base para as demais foi a ISO 14001 e o objetivo dela é garantir a redução da carga de poluição gerada pelas organizações, porque envolve a revisão de um processo produtivo visando à melhoria contínua do desempenho ambiental, controlando insumos e matérias-prima que representem desperdícios de recursos 
naturais, e esses fatores terminam por verificar se a política da empresa implantada e citada em NBR 14004 (1996 apud GUMERATO, 2003):

- Avalia as consequiências ambientais das atividades, produtos e serviços da organização;

- Atende a demanda da sociedade;

- Define políticas e objetivos baseados em indicadores ambientais definidos pela organização que podem retratar necessidades desde a redução de emissões de poluentes até a utilização racional dos recursos naturais;

- Implicam na redução de custos, na prestação de serviços e em prevenção;

- É aplicada às atividades com potencial de efeito no meio ambiente;

- É aplicável à organização como um todo.

Certificar um Sistema de Gestão Ambiental significa comprovar junto ao mercado e a sociedade que a organização adota um conjunto de práticas destinadas a minimizar impactos que imponham riscos à preservação da biodiversidade. Com isso, além de contribuir com o equilíbrio ambiental e a qualidade de vida da população, as organizações obtêm um considerável diferencial competitivo fortalecendo sua ação no mercado (MOREIRA, 2001).

A certificação ocorreria a partir de uma empresa homologadora, que fiscalizaria as empresas certificadas. Para pleitear um certificado da série ISO 14000, uma indústria deve tomar medidas para reduzir os problemas ambientais causados pelos processos produtivos que emprega. Além disso, os impactos ambientais do produto têm de ser analisados desde as fontes energéticas que vai consumir, passando pelos materiais, sua vida útil e destinação após o uso. Outra inovação importante da série ISO 14000 é que a responsabilidade jurídica de possíveis problemas ambientais fica para o proprietário da empresa, em vez de recair isoladamente sobre um técnico (VALLE, 2002).

Atualmente a procura por essa certificação está cada vez maior, principalmente pelo aumento da consciência da população em relação a proteção do meio ambiente e a preferência dada a empresas que já têm atitudes positivas com relação a esse fim. Não há exigência internacional oficial para as empresas alcançarem a certificação, porém isto não significa que 
não há pressão para a obtenção da certificação ISO 14001, elas são opcionais dentro das empresas (GUMERATO, 2003).

As empresas, em especial as associadas à poluição ambiental, estão entre as principais a buscar a certificação ISO 14001. Mais de 2500 empresas instaladas no País já contam com a certificação, justificada por motivos diversos, que vão desde legítimas preocupações com a proteção ambiental até o uso como ferramenta de propaganda local e internacional. Isto porque as grandes empresas como PETROBRAS, Aracruz Celulose e as grandes montadoras de automóveis estão "sugerindo" a seus fornecedores que também se certifiquem. Um problema verificado nos dias de hoje é que conforme a lei foi criada no moldes internacionais, ela está apresentando dificuldades como incluir o desempenho ambiental na série, dados a desconfiança na efetividade da norma e os diferentes graus de maturidade da indústria ao redor do mundo (VALLE, 2002).

A própria norma já possui um foco indireto em outro conceito muito ligado a gestão ambiental e que na verdade possui como um de seus pilares a questão da preservação do meio ambiente, lembrando que devemos preservar hoje para que não falte para as gerações futuras. Ainda assim se faz necessário abordar o tema do desenvolvimento sustentável, assunto este que está em cada vez mais presente na pauta de discussões políticas de empresas e governos, salientando da importância de se considerar outros fatores além dos econômicos.

\subsection{Desenvolvimento Sustentável}

Este conceito tão discutido cada vez mais nos dias de hoje, principalmente, pelas discussões que se dão em torno do esgotamento dos recursos naturais que foi definido pela Comissão Mundial sobre Meio Ambiente e Desenvolvimento da ONU como sendo: "o desenvolvimento capaz de suprir as necessidades da geração atual, sem comprometer a capacidade de atender as necessidades das futuras gerações. É o desenvolvimento que não esgota os recursos para o futuro", e este é considerado o conceito mais aceito com relação ao tema no mundo.

No Brasil a preocupação com este tema se faz principalmente após a criação da Agenda 21, já citada no tópico de gestão ambiental e que foi criada com bases sobre o desenvolvimento sustentável. Desde 2002 o IBGE vêm fazendo um esforço na criação de indicadores para o monitoramento deste tema e suas variáveis. Falando mais especificamente das variáveis ambientais, estas são apontadas no último relatório de 2008 como sendo 
organizadas através dos temas: atmosfera, terra, água doce, oceanos, mares e águas costeiras biodiversidade e saneamento. Como o tema ambiental é mais recente, o relatório também aponta que não existe uma gama considerável de dados estatísticos sobre o tema, o que termina por dificultar a criação de indicadores mais precisos.

Atribuiu-se uma maior importância ao tema quando veio a reflexão sobre o conceito de Desenvolvimento Econômico, sustentado em grande parte pela própria idéia acerca do PIB, onde o importante para a população e desenvolvimento de uma nação é somente os fatores econômicos. Quando o conceito do desenvolvimento sustentável foi posto em comparação ao econômico, verificou-se que o segundo já não retratava mais a realidade no qual atuamos. Deve-se estar ciente de que os recursos naturais não são inesgotáveis e que os direitos humanos devem ser respeitados. Foi concluído, após séculos de utilização do mesmo pensamento, que o crescimento de uma nação, empresa, ou país não é justificado somente por seus resultados financeiros, mas também por todas as conseqüências envolvidas em seus processos de produção (OLIVEIRA, 2006).

Ainda sobre essa diferenciação entre desenvolvimento e crescimento, Sachs (2004) coloca a idéia de que o desenvolvimento vai muito além do que apenas a multiplicação da riqueza material, mas abrange metas de desenvolvimento humano onde as pessoas objetivam uma qualidade de vida melhor. Ele ainda propõe que o desenvolvimento é embasado por um pensamento que leva a redução das desigualdades, havendo uma maior distribuição entre os atores, sendo estes países, empresas ou pessoas, para que estes possam ter maiores oportunidades frente aos agentes dominantes e obtenham uma maior fonte de recursos.

Para que se tenha um desenvolvimento sustentável eficiente se faz necessário haver um balanço de equilíbrio entre a sustentabilidade ambiental e social, pois em alguns casos, projetando ganhos em algum dos fatores em curto prazo, termina por causar sérios danos no outro. Por isso devemos fundamentar as estratégias em cinco pilares apresentados por Sachs (2004):

- Social;

- Ambiental;

- Territorial; 
- Econômico;

- Político.

$\mathrm{O}$ autor ainda menciona que para haver um progresso nestes cinco pilares, se faz necessária uma ação de ordem global, como a criação de estratégias que possam conciliar interesses entre os países do Norte e do Sul. Dessa forma haveria uma maior distribuição de benefícios e criaria uma situação mais igualitária de competição. Alguns fatores ainda são apresentados como sendo fundamentais para o sucesso da estratégia desenvolvimentista, como o apoio a geração de empregos, tendo como consequiência uma maior distribuição de riquezas, e o próprio apoio ao desenvolvimento das pequenas e grandes empresas nacionais.

Para justificar que o fator de geração de empregos seja um dos pilares principais para que os países alcancem o desenvolvimento sustentável, Sachs (2004) ainda faz algumas sugestões de planejamento estratégico para os países em desenvolvimento. Estes deveriam direcionar os investimentos a atividades que fortaleçam as empresas nacionais, reduzindo primeiramente a dependência externa. Outro ponto é o investimento concentrado em setores que estimulem a geração de empregos principalmente as classes mais pobres, para que estas possam se desenvolver e desconfigurar a sua alta dependência do assistencialismo do governo. Além disso, ainda temos a formalização das atividades, o investimento em setores de serviços e atividades de materiais não comercializáveis, como a pequena produção rural, o artesanato, entre outros. Se colocando no papel do Estado ainda se tem as políticas fiscais que reduzam a alíquota sobre bens essenciais e aumente sobre os considerados de luxo, assim como o aumento de investimentos na educação, saúde e moradia, bens básicos e essenciais para que uma pessoa possa ter uma vida com dignidade.

Um último ponto abordado pelo autor é o direcionamento de fundos para segmentos que possam trabalhar com a reutilização de materiais e preservação dos bens naturais, custos hoje que gerarão grandes economias futuras, além de incentivar as empresas a desenvolverem políticas de incentivo a economia de recursos, pois estes geram um grande peso na parte contábil da empresa e que termina por onerar o preço final para os clientes e consequientemente as vendas. 


\subsection{O shopping Pátio Brasil}

Após a identificação da necessidade dos moradores de Brasília por um número maior de centros de entretenimento e negócios, foi decidida por um grupo de investidores a construção do shopping Pátio Brasil.

Este foi inaugurado em 1997, época no qual o segmento era controlado por dois outros shoppings, o Conjunto Nacional e o Park Shopping, e devido ao aumento substancial da população de Brasília foram analisados e identificados uma oportunidade de negócios ainda não explorada.

Localizado no setor comercial sul, atualmente o Pátio Brasil Shopping possui uma circulação média de 1,5 milhões de pessoas por mês. Esse fato é atribuído em grande parte a sua localização próxima a escritórios, colégios e a Rodoviária de Brasília, e devido tembém a sua grande opção de refeições na praça de alimentação e lojas ao longo de seus cinco pavimentos - com 200 lojas e 25 restaurantes.

Outro fator de sucesso atribuído ao shopping vem em acordo com a pesquisa realizada pela ABRASCE, onde são apresentados os resultados positivos dos shoppings brasileiros nos últimos anos e se atribui este fato não só ao aquecimento da economia, mas também a boa gestão destes empreendimentos. No caso do Pátio Brasil Shopping, o negócio é gerenciado por um grupo português atuante em diversos setores da economia, chamado Sonae (Sociedade Nacional de Estratificados).

O shopping atualmente conta com a execução de diversos programas ligados a área de políticas ambientais, dentre os programas que possuem o contato direto com o público consumidor final, destacam-se as lixeiras de coleta seletiva espalhadas por todo o prédio, assim como as lixeiras coletoras de resíduos específicos na praça de alimentação. O projeto de coleta de lâmpadas fluorescentes também apresenta um grande destaque, envolvendo grandes esforços de marketing para a sua divulgação. Dentre as ações indiretas, se têm a política de redução de água, energia e reaproveitamento de resíduos gerados pelo shopping, ações estas que possuem metas e são exigidas pela própria matriz administrativa do negócio. Abaixo segue a lista de todas as ações realizadas atualmente pelo shopping:

- Atuação em conformidade com a legislação e normas ambientais; 
- Coleta Seletiva de lixo produzido em todas as lojas e instalações;

- Controle do consumo de água e energia;

- Utilização de papel reciclável em todo o material de expediente;

- Reciclagem de lâmpadas para a retirada de substâncias tóxicas;

- Monitoramento periódico para análise de qualidade do ar, da água e efluentes;

- Máximo aproveitamento da luz natural em todas as dependências;

- Uso de depósitos especiais para produtos químicos e lubrificantes;

- Recolhimento de pilhas e baterias;

- Eventos de consciência ambiental para lojistas e consumidores;

- Decoração de natal ecologicamente correta.

Com relação a caracterização da estrutura administrativa do shopping, se têm como característica estrutural a não existência de uma área especifica para a gestão ambiental, ou seja, indo em acordo com a teoria onde a responsabilidade é compartilhada por entre as áreas da empresa, tendo cada uma atribuições específicas junto a este objetivo. Para a melhor visualização segue organograma do shopping Pátio Brasil representado na figura 1 a seguir: 
CONDQMínIo Do PATIO BRASIL SHOPPING

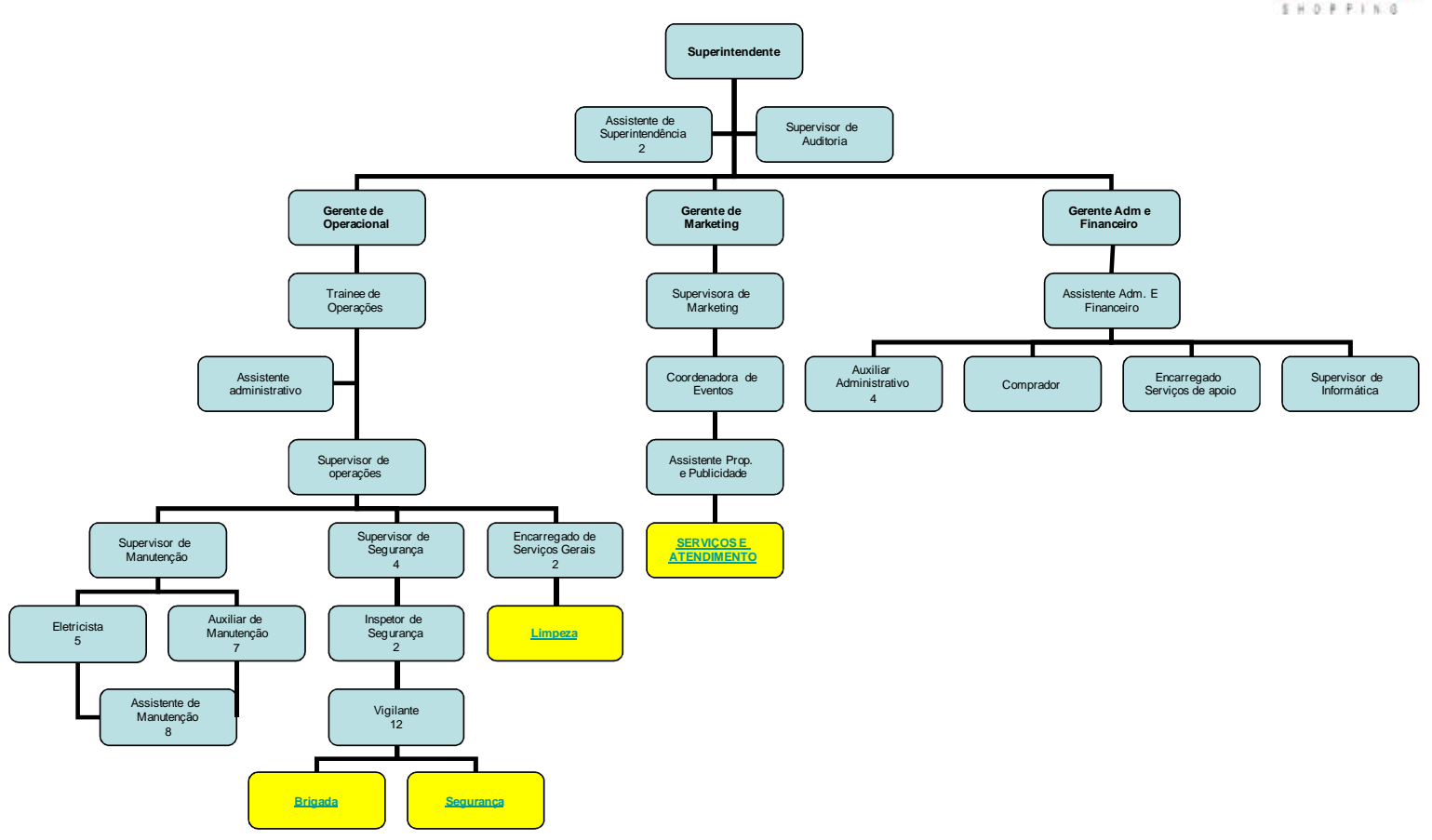

Figura 1: Organograma da administração do shopping Pátio Brasil.

Fonte: Shopping Pátio Brasil. Abril, 2009.

Pode-se verificar que a estrutura administrativa do shopping é diferente de outras estruturas organizacionais de empresas que atuam no setor de serviços, mas isso é justificado pela própria estrutura da empresa de funcionamento, tendo um grupo administrador externo que determina as orientações gerais e que será correlacionado no próximo tópico.

\subsection{Grupo Sonae Sierra: Grupo administrador do shopping Pátio Brasil}

O grupo Sonae ganhou uma importância ainda maior nos últimos anos por ser o primeiro gestor de shoppings a atribuir em sua lista de ferramentas de gestão, ações voltadas para a gestão ambiental e desenvolvimento sustentável, obtendo a partir dai o certificado ISO 14001.

No Brasil a sua atuação é realizada através da administração de nove shoppings situados nos estados de São Paulo, Rio de Janeiro e no Distrito Federal.

Esta posição da empresa em pró da preservação do meio ambiente pode ser justificada ao analisar a sua política de sustentabilidade e a sua lista de valores e princípios mostrando a atuação da empresa em torno da Consciência Ambiental como sendo: "melhorar de uma 
forma contínua o desempenho ambiental dos seus produtos, processos e atividades", dentre outros fatores que nos remetem aos conceitos de responsabilidade social empresarial e desenvolvimento sustentável.

É interessante ainda mencionar que na própria política da empresa foram organizadas subdivisões onde se procurou organizar ações junto a compromissos traçados com Organizações Internacionais, como no caso da responsabilidade ambiental que aponta as sua empresa como tendo uma abordagem preventiva que favorece o meio ambiente, além do fomento sobre o desenvolvimento de iniciativas que promovam uma maior responsabilidade ambiental.

A fim de se organizar e criar uma estratégia efetiva para com a proteção do meio ambiente em suas atividades, o grupo Sonae dividiu a estratégia ambiental da empresa em tópicos de impactos materiais, sendo eles, alterações climáticas, água, resíduos e uso do solo. Ainda é informado no site do shopping Pátio Brasil que a empresa acredita em investimentos na gestão ambiental, pois esta contribui para com a redução de riscos e custos.

A orientação do grupo administrador do shopping para tornar estas ações efetivas é a implantação do Sistema de gestão ambiental (SGA) em acordo com as normas ISO 14001 e 14004, e o SGA tem como objetivo final o aumento da eco-eficiência e controle dos impactos ambientais, e este é realizado segundo apresentado na figura 2 a seguir:

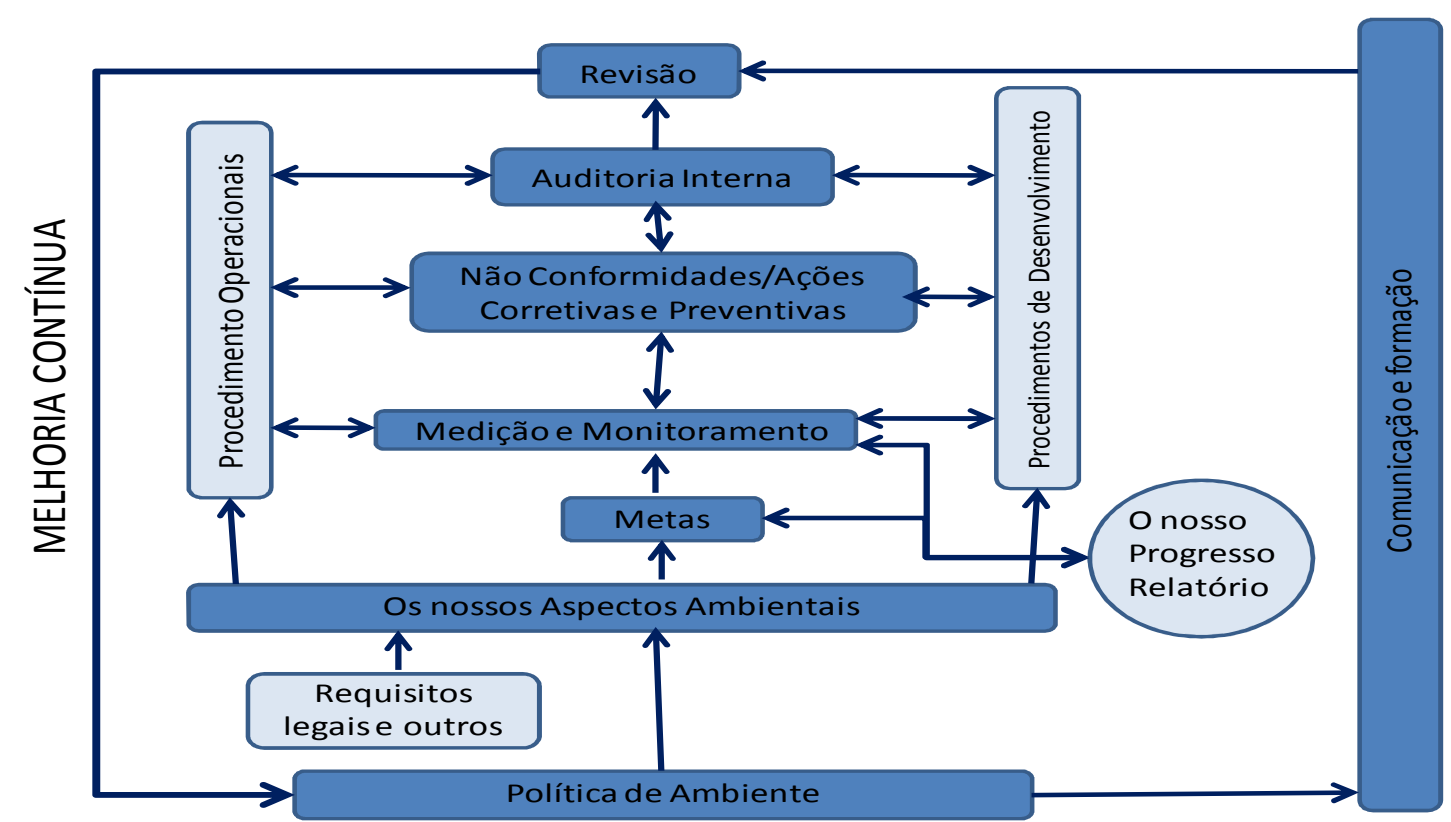

Figura 2: Sistemas de gestão ambiental - Grupo Sonae Sierra.

Fonte: Grupo Sonae Sierra. <http://www.ambiente.sonaesierra.com/Public/Normal/ptPT/gestaoambiente/sga.aspx> Março, 2009. 
As informações acerca da atuação do Pátio Brasil foram encontradas no site do próprio shopping, onde há também um redirecionamento para o chamado Portal do Ambiente, site este do grupo Sonae e que procura explicar como funciona a metodologia de aplicação do SGA, além do desempenho de seus indicadores nos últimos anos analisados (período compreendido até o fim de 2007). Porém, não é mostrado o desempenho específico de todos os shoppings administrados no Brasil, inclusive, nas metas como de obtenção da certificação ISO 14001, eles mostram que dois shoppings, o Parque Dom Pedro e o Shopping Penha, foram os primeiros centros deste segmento a possuírem a certificação no país, e quanto ao primeiro shopping foi apresentado no relatório de desempenho como exemplo de eficiência em muitos dos fatores analisados sobre os shoppings sob a administração do grupo no mundo. A meta até Novembro de 2008 era a certificação de sete centros comerciais no Brasil, não especificando quais seriam estes.

Analisando a política ambiental do grupo, percebe-se a real importância que este atribui as consequiências de suas ações ao meio ambiente, colocando pontos como a que um líder nos negócios tem de ser igualmente líder nas questões relacionadas ao meio ambiente, assim como todas as atividades realizadas pelo ser humano, possuem algum impacto no meio ambiente.

Dessa forma, a empresa deve atuar buscando métodos que possam contribuir para a proteção frente ao direito de disponibilização dos recursos naturais as gerações futuras. A empresa ainda coloca que a sua atuação será feita de maneira eco-eficiente, independente de existência de legislação ou não que regule as atividades e buscando sempre a melhoria de seus processos e produtos para a obtenção de resultados positivos ante a gestão ambiental.

Tratando mais especificamente dos tópicos de atuação da empresa, se faz necessário o detalhamento maior de cada um dos fatores de atuação, que é apresentado abaixo:

- Água: Quanto a este fator, o grupo verificou que as atividades de empresas relacionadas ao segmento imobiliário, possuem um alto impacto desde o momento da construção dos edifícios até durante a operacionalização do uso do empreendimento. Visto esta situação, a empresa procura realizar o monitoramento do consumo de água de seus negócios, assim como a adoção de ações como a reutilização da água cinzenta, implantação de sistemas de torneiras, bebedouros e descargas que utilizem menos água. 
- Durante a fase de construção, são realizados trabalhos para a coleta da água utilizada, assim como o seu tratamento, e são feitos acordos com as construtoras de compromisso para com a não poluição das águas superficiais e subterrâneas.

- A gestão deste recurso é realizada através de uma ferramenta on-line, onde os responsáveis pelo seu controle podem gerar dados sobre o consumo e realizar comparativos com os demais shoppings ao redor do mundo.

- O indicador utilizado para o controle da água é visitante (litros/visita), porém a meta estipulada já foi alcançada e por isso estão pensando em revê-la brevemente.

- Resíduos: A gestão de resíduos se torna uma tarefa muito importante e difícil atualmente, pois depende de muitas variáveis, inclusive da mudança de cultura dos agentes envolvidos. Com a finalidade de melhorar essa situação, diminuindo a utilização dos aterros sanitários e reutilizando parte dos resíduos eliminados, a administração dos shoppings deve seguir os seguintes princípios: "Reduzir, Reutilizar, Reciclar e Eliminar".

- Para se fazer frente a este objetivo, a empresa realiza estudos visando identificar possibilidades de reciclagem e redução do uso dos aterros, e seu monitoramento é feito através da porcentagem de resíduos reciclados e da taxa de resíduos enviados para aterros. Atualmente a meta de longo prazo é de $50 \%$ de reciclagem e $30 \%$ de utilização dos aterros. Este trabalho é realizado pela própria empresa e em associação com outras prestadoras de serviços.

- Alterações Climáticas: Para se fazer frente a este fator, o grupo Sonae verificou que deveria traçar ações visando a busca e utilização de energias renováveis além da utilização de equipamentos que não possuíssem emissão de gases que contribuam ao aumento do efeito estufa. Afim de que este processo pudesse ser acelerado, o grupo se associou ao World Business Council (WBC) no Projeto para o Desenvolvimento Sustentável da Eficiência Energética em Edifícios (EEB). Este projeto tem como objetivo a identificação de alterações que podem ser realizadas nos edifícios afim de atuar com o consumo zero de energia, e a entrega deste relatório está prevista para o ano de 2009. 
- O monitoramento deste fator é realizado através de um indicador de gás carbônico onde são calculados em forma de função das toneladas do gás equivalente emitida por unidade de área e por visitante por centros, além da utilização de outros KPIs (Key Performance Indicators) para o monitoramento de aspectos ligados a eficiência energética e as formas de transporte.

- Uso do solo: O grupo Sonae acredita que a má utilização de uso do solo pode gerar conseqüências gravíssimas para o ecossistema do planeta, gerando alterações as vezes irreversíveis na qualidade do solo, ar e água.

- A empresa possui a diretriz de tentar desenvolver novos negócios em terrenos previamente ocupados, para que mantenha a preservação dos lotes não urbanizados e não afetados por ações do ser humano. Passando dessa forma para o chamado "browfield", ou terrenos que já foram utilizados, porém é feito um estudo sobre a área com a meta de recuperação do solo e mesmo a sua preservação durante o período que esta será utilizada.

- Esta ação tem o objetivo de preservar o solo para possíveis necessidades futuras, e seu KPI em relação a este fator é a proporção de projetos concluídos em terrenos previamente urbanizados.

Os procedimentos de desenho e concepção são suportados por uma ferramenta desenvolvida internamente e chamada de Environment Standards for Retail Developments ESRD. Esta ferramenta proporciona aos gestores, uma série de fatores que devem ser controlados e que podem ser comparados com o desempenho dos demais empreendimentos, sendo este procedimento realizado totalmente on-line.

A análise das metas ambientais do grupo Soane é auditada pela empresa Deloitte ano a ano visando a melhoria contínua dos processos e o aperfeiçoamento dos critérios de avaliação utilizados. Para o ano de 2008 as metas foram organizadas conforme os fatores já mencionados neste texto e ainda estão sendo analisadas para fim de confecção do relatório. As metas são apresentadas no site da empresa, conforme mostra a tabela 1 a seguir: 


\begin{tabular}{|c|c|}
\hline Fator analisado & Meta estipulada \\
\hline Água & $\begin{array}{l}\text { Conseguir uma redução de } 1 \% \text { no consumo total em todos os centros } \\
\text { comerciais detidos que estiveram em operação durante todo o ano civil de } \\
2008 \text {. }\end{array}$ \\
\hline \multirow{2}{*}{ Resíduos } & Atingir, no mínimo, uma taxa de reciclagem global de $36 \%$. \\
\hline & Reduzir a taxa de resíduos enviados para aterro em $2 \%$. \\
\hline Alterações Climáticas & $\begin{array}{l}\text { Atingir uma redução de } 1 \% \text { nas emissões de gases com efeito de estufa por } \\
\text { metro quadrado de Área Bruta Locável comparado com o nível de } 2007 \\
\text { (âmbitos } 1 \text { e } 2 \text { do protocolo GHG). }\end{array}$ \\
\hline Uso do solo & $\begin{array}{l}\text { Atingir } 100 \% \text { de conformidade com a implementação da Avaliação Preliminar } \\
\text { de Ambiente. }\end{array}$ \\
\hline \multirow[t]{2}{*}{ Gestão Ambiental } & $\begin{array}{l}\text { Assegurar que os projectos atingem pelo menos } 25 \% \text { da máxima pontuação } \\
\text { possível em relação aos requisitos de Liderança aplicáveis. }\end{array}$ \\
\hline & $\begin{array}{l}\text { Conseguir a certificação ISO } 14001 \text { da gestão da obra de 100\% dos centros } \\
\text { comerciais até ao dia de inauguração (por número). }\end{array}$ \\
\hline
\end{tabular}

Tabela 1: Fator analisado X Meta estipulada.

Fonte: Grupo Sonae Sierra. <http://www.ambiente.sonaesierra.com/Public/Normal/pt$\mathrm{PT} /$ gestaoambiente/metas.aspx>. Março, 2009.

As metas apresentadas no quadro são consideradas como sendo de ordem geral, abrangendo os cinco campos de atuação das políticas ambientais do grupo, entretanto estas metas não são únicas, pois para se conseguir melhor visualização e controle destas, elas são divididas em sub-metas menos amplas e quem tem como objetivo final o alcance das macros existentes no quadro. 


\section{MÉTODOS E TÉCNICAS DE PESQUISA}

A partir da taxonomia apresentada por Vergara (1990) a pesquisa pode ser classificada quanto aos fins e quanto aos meios. Os métodos e procedimentos a serem desenvolvidos buscam clarificar a pesquisa e responder suas principais indagações. Ainda segundo Marchetti (2000 apud Vieira, 2002: 66) o método mais adequado a ser optado para utilização em determinada pesquisa vai depender diretamente de alguns fatores como: "Definir qual é o objetivo em cada pesquisa; escolher as técnicas de pesquisa; desenvolver os instrumentos de medida; desenvolver um plano de amostragem; e por fim definir o tipo de análise dos dados."

A fim de responder o questionamento principal foi realizada uma pesquisa descritiva, tendo como objetivo "expor características de uma determinada população e um fenômeno" (VIEIRA, 2002: 65). Tratando-se de pesquisa descritiva, deve ser considerado que esta pode assumir diversas formas de estudo, como pesquisa de opinião, estudo descritivo, estudo de caso, entre outros. No presente estudo se optou por analisar os elementos da pesquisa através de estudo de caso, buscando identificar variáveis atuantes no shopping Pátio Brasil através do ponto de vista dos agentes envolvidos, para que assim se possa criar um panorama acerca do tema no segmento de shopping centers.

Quanto aos meios, trata-se de uma pesquisa de campo, uma vez que é uma investigação empírica que se pretende realizar no local de pesquisa. E também uma pesquisa bibliográfica, pois esta sendo realizado um estudo aprofundado sobre o tema, com consultas em revistas e livros e artigos científicos.

Para a realização da análise junto aos gestores do shopping, foi utilizado pelo pesquisador um questionário estruturado contendo questões fechadas e apenas uma aberta para finalidade de coleta de sugestões. No caso dos gerentes de lojas, foi utilizado um questionário com os mesmos princípios do utilizado com os gestores, porém com uma adequação das perguntas, visando atender ao foco de atuação destes frente as políticas ambientais de modo diferente, sendo mais agentes do que gestores ou planejadores. E para a realização da pesquisa junto ao terceiro grupo, dos funcionários de apoio, foi utilizada a metodologia que realiza a coleta de dados através da observação no próprio local de trabalho e no desenvolver de suas atividades, não havendo a interferência do pesquisador. 


\subsection{Delineamento da pesquisa}

Foi determinada a utilização destes tipos de pesquisa, visto a diferença de interferência e atuação destes agentes junto a gestão ambiental da empresa. A abordagem junto aos gerentes administrativos e lojistas foi caracterizada como descritiva, pelo caráter de análise do estudo que terá como objetivo, descrever o modo pelo qual a organização vem transformando as políticas ambientais estabelecidas em ações reais.

$\mathrm{Na}$ etapa que envolveu a coleta de dados através da observação, foi julgado que o grupo analisado poderá contribuir mais, sendo analisados sob o aspecto de atuação de seu trabalho, sabendo que estes possuem um papel fundamental junto as ações de gestão ambiental, pois contribuem em atividades preponderantes como a própria seleção do lixo e orientação do consumidor final do shopping.

\subsection{Descrição das variáveis de pesquisa}

Após a identificação da necessidade de utilização de questionários para a coleta de dados, é importante uma análise dos pontos fundamentais que se pretende extrair dos entrevistados, assim como delinear qual seria a melhor maneira ou tipo de pergunta para se obter estas informações.

Devido a algumas características da amostra como número de entrevistados, tempo disponível para entrevista, nível educacional e categorização de respostas por grupos optou-se de maneira geral pela utilização de perguntas fechadas ou estruturadas, deixando apenas as questões acerca de sugestões e áreas organizacionais que o entrevistado pertence como abertas ou não-estruturadas. Ambos os tipos de questões possuem vantagens e desvantagens, tendo suas utilizações determinadas pelo tipo de informação que se pretende obter e público que está sendo abordado. Segundo Malhotra (2006), as perguntas abertas possuem uma influência tendenciosa muito menor do que as fechadas, pois neste tipo de questão o entrevistado possui o direito de expor as reais percepções e sugestões sobre determinado tema, deixando-o um espaço muito maior a revelar o seu real ponto de vista, porém este tipo de pergunta gera um grande problema de codificação dos dados pelo entendimento de respostas e tamanho. Já as perguntas não estruturadas ajudam o pesquisador a identificar de maneira mais simplificada alguma tendência que esteja acontecendo pela delimitação de respostas e mesmo a categorização de informações, além da facilidade de coleta e tabulação dos dados (MALHOTRA, 2006). 
Em relação às perguntas não-estruturadas, estas podem ser tipificadas de diversas formas, porém devido a finalidade deste estudo, foram escolhidas apenas as perguntas dicotômicas, de múltipla escolha e escala Likert. As perguntas dicotômicas foram utilizadas com a finalidade de obter informações de maneira direta dos entrevistados, através do questionamento de situações onde a resposta poderia ser uma afirmação ou não. Já as questões de múltipla escolha foram utilizadas em situações onde o entrevistado teria que optar por uma ou mais categorias, tendo como objetivo captar através de uma mesma questão dados acerca de pontos semelhantes. Collis et alli (2005) coloca alguns pontos com relação a utilização deste tipo de questão, como a vantagem no momento de processamento dos dados e velocidade na sua captação, assim como a avaliação de diversos fatores em uma só questão, mas ao mesmo tempo procura lembrar das dificuldades de elaboração deste tipo de pergunta, principalmente na determinação de opções de resposta, pois pode haver a falta de abordagem de algum ponto.

Fazendo referência a escala Likert, Brandalise (2005) relembra que "o consumidor constrói níveis de aceitação dos produtos e serviços, conforme suas experiências e influências sociais" e pensando analisar esta idéia que Rensis Likert elaborou a sua escala em 1932. Baker (1995) complementa esta idéia, dizendo que esta escala é utilizada para que o entrevistado indique o seu grau de concordância ou discordância a uma determinada variável que está sendo pesquisada, e estes fatores de resposta terminam por receber uma pontuação numérica para referenciar ao seu grau de favorecimento de atitude. Como os demais tipos de pergunta, a escala Likert também apresenta vantagens e desvantagens, e Brandalise (2005 apud MATTAR, 2001: 04) mostra a escala tendo como fatores positivos "a simplicidade de construção, o uso de afirmações que não estão explicitamente ligadas à atitude estudada, permitindo a inclusão de qualquer item que se verifique, empiricamente, ser coerente com o resultado final; e ainda, a amplitude de respostas permitidas apresenta informação mais precisa da opinião do respondente em relação a cada afirmação. Como desvantagem, por ser uma escala essencialmente ordinal, não permite dizer quanto um respondente é mais favorável a outro, nem mede o quanto de mudança ocorre na atitude após expor os respondentes a determinados eventos".

Após a caracterização das variáveis de pesquisa utilizadas neste estudo, se faz necessário como próximo passo a abordagem da população que será analisada, apresentando fatores específicos dos agentes estudados e determinação da amostra. 


\subsection{População e amostra}

Este estudo abrange um empreendimento do segmento de shopping centers, tendo a pesquisa como foco de atuação alguns agentes que estão envolvidos no fluxo de negócios deste tipo de organização, como os gestores administrativos, os gerentes das lojas e os funcionários do shopping, sendo estes caracterizados como de atividades de apoio. Dessa forma, foi realizada uma pesquisa de caráter geral descritiva, onde se buscou analisar os impactos das ações de gestão ambiental nas atividades destes atores assim como os fatores que influenciam a sua execução.

A coleta dos dados foi realizada com toda a população dos gestores internos do shopping, assim como com uma amostra não probabilística dos gerentes de lojas e uma amostra não probabilística acidental dos funcionários de apoio do shopping. Para a investigação junto aos gestores administrativos, a amostra ficou limitada a cinco questionários, abordando dessa forma todos os gestores de alto escalão da empresa e que possuem poder de decisão na empresa. Os funcionários de apoio foram analisados pelo método da observação seguindo pontos definidos em um roteiro previamente estruturado, tendo ao final a amostra formada por dez funcionários de apoio.

A quantidade total de lojas e restaurantes no shopping é de duzentos e vinte e cinco estabelecimentos, mas para a análise foram desconsideradas a pedido da própria administração do shopping, as quatro agências bancárias e as treze joalherias, além disso, os trinta e nove quiosques por terem estruturas particulares e bem diferenciadas das lojas, inclusive na sua forma de atuação, as mesmas não foram analisadas nesta pesquisa. Portanto a população inicial sob estudo seria de cento e sessenta e nove empreendimentos.

Por ser uma pesquisa de caráter externo, alguns agentes preferiram não participar da pesquisa, havendo dessa forma um decréscimo ainda maior na população a ser analisada, mas ainda com uma amostra final bastante significativa e que através da metodologia de Barbetta (2002) resultando em um erro amostral de aproximadamente 10\% (Amostra estimada $=1$ /Erro amostral elevado ao quadrado) e uma amostra total de noventa e oito gerentes de lojas. 


\subsection{Procedimentos e instrumentos utilizados na coleta e análise dos dados}

Segundo Roesch (2006) as entrevistas podem ser classificadas em estruturadas quando há certa liberdade de perguntas e de respostas, ou podem ser estruturadas quando seu foco principal é uma seqüência pré-determinada de questões e por último podem ser semiestruturadas, caso em que o entrevistador segue pontos a serem focalizados, mas pode se desejar se aprofundar melhor em cada tema e construir questões abertas.

A pesquisa realizada foi caracterizada como sendo uma pesquisa de campo de investigação empírica e executada no local sob análise. Buscando através de dados quantitativos averiguar a percepção dos agentes sobre a questão em análise, atuando em três grupos de investigação com o auxílio de questionários. A realização da revisão na literatura está contemplada para sistematizar, os materiais de pesquisa são: livros, revistas acadêmicas, redes eletrônicas, etc.

Para este estudo optou-se por questionários semi-estruturados uma vez que serão realizadas perguntas pré-definidas, mas existe a possibilidade de exploração diferenciada em algumas questões caso o entrevistador considere necessário, realizando dessa forma questões abertas. Os questionários definidos são bem semelhantes e buscam através da pesquisa comparar o ponto de vista dos agentes analisados, assim como o roteiro de avaliação prédefinido e utilizado com o terceiro grupo de elementos observados.

\subsection{Período de realização da pesquisa}

O procedimento de coleta dos dados foi realizado nos dias 20, 21 e 22 de Maio de 2009, no período da manhã, tarde e noite.

\subsection{Comentários sobre o processo da coleta de dados}

O procedimento de análise dos dados será realizado com o auxílio do software Microsoft Office Excel, gerando através da base de dados, planilhas e tabelas que possam resumir os dados coletados e transformá-los em informações úteis as análises propostas.

Dessa forma, identificar-se-á o perfil dos entrevistados, assim como a percepção dos mesmos acerca do tema sob estudo. 


\section{APRESENTAÇÃO E ANÁLISE DOS RESULTADOS DA PESQUISA}

Por se tratar de um estudo onde foram analisados diferentes elementos atuantes no mesmo ambiente de trabalho, buscar-se-á através deste capítulo, mostrar as informações obtidas através de tópicos, onde cada grupo terá seus dados analisados separadamente. Os dados que serão mostrados nesta parte do trabalho, são analisados juntamente com as idéias apresentadas no referencial teórico deste estudo, buscando muitas vezes a retomada de idéias a fim de comparar a literatura estudada e os dados obtidos através da pesquisa.

No último tópico, através de gráficos e tabelas, serão mostradas características das amostras analisadas, assim como dados quantitativos de comparação entre os agentes sob estudo. Devido ao tamanho das amostras, ficou caracterizada a ilustração dos dados obtidos com os gerentes das lojas através de gráficos, porém os dados sobre os gestores administrativos do shopping Pátio Brasil serão retratados através de tabelas, pelo número reduzido da população analisada.

\subsection{Agrupamento, ordenação e descrição dos dados coletados}

Atualmente a administração do shopping Pátio Brasil está tratando o tema gestão ambiental com focos de atuação em clientes internos e externos. Através disso, pode ser verificado que em todas as áreas do shopping, sendo estas internas ou externas, possuem um ambiente orientado para por em prática as políticas ambientais da empresa. A administração do shopping possui um programa bem estruturado de gestão ambiental, tendo algumas de suas ações agendadas previamente no cronograma de atividades do shopping. Atividades como palestras aos lojistas, clientes e funcionários.

Os programas que envolvem os clientes externos possuem uma ampla divulgação procurando realmente envolver a sociedade e mostrar a preocupação e empenho que o shopping vem tendo a respeito da gestão ambiental, assim como a responsabilidade social e o desenvolvimento sustentável.

A forma de atuação do shopping junto aos clientes internos é bastante intensa, tendo diversos programas e palestras voltados ao tema, dados estes relatados pela própria administração, porém a comunicação se mostra um pouco ineficiente com os lojistas. Sendo caracterizados pelo baixo conhecimento acerca do que está sendo executado em termo de 
ações ambientais, dado este identificado através dos questionários, mas ao mesmo tempo pelo baixo coro participativo nas palestras e reuniões relacionadas ao tema.

Apesar dos indicadores estarem sendo apresentados em diversos murais internos ao shopping, verifica-se que os mesmos são acompanhados mais por determinação do próprio grupo administrador Sonae Sierra e não por um envolvimento dos agentes impactados. Dessa forma, pode ser observado que apesar no baixo envolvimento, resultados positivos ainda vem sendo alcançados, porém uma falha de estratégia acerca da gestão ambiental é bem marcante, não tendo o envolvimento de todos os stakeholders em suas ações. O impacto desta deficiência pode não ser considerável atualmente, mas quando as metas se tornarem mais agressivas, o comprometimento de todos os indivíduos será determinante e um novo foco estratégico deverá ser desenhado.

\subsection{Análise descritiva dos dados}

Conforme definido na metodologia da pesquisa, este estudo teve um foco de análise em diversos agentes considerados como determinantes no sucesso das ações ambientais realizadas pelo shopping. Dessa forma, este tópico sobre a análise dos dados abordará uma discussão acerca das informações obtidas com cada grupo ou aspecto analisado, assim como a análise do setor.

\subsubsection{Análise geral do setor de shopping centers no Brasil}

O setor de shopping centers deve ser levado em consideração quando nos referimos aos dados econômicos do país, principalmente quando passamos a analisar os resultados frente a uma dimensão nacional, tendo segundo dados encontrados no site da ABRASCE (Associação brasileira de shopping centers, 2009) o setor responsável por 18,3\% do varejo nacional e 2\% do PIB. Ainda é importante salientar o crescimento que este vem obtendo nos últimos anos, como a taxa de $28 \%$ caracterizada entre os anos de 2006 e 2008. Os resultados alcançados mostram um desenvolvimento acima da própria economia, e justificado pelo grande volume de investimentos estrangeiros, abertura de capitais das empresas na bolsa de valores e pelo desempenho positivo da gestão dos administradores.

Podemos ainda resumir alguns dados específicos sobre o desempenho do setor, obtidos em Janeiro de 2009, e resumidos nas tabelas 2, 3 e 4 apresentados a seguir: 


\begin{tabular}{|l|r|}
\hline \multicolumn{2}{|c|}{ Grandes Números: Brasil em Janeiro de 2009} \\
\hline Número Total de Shopping Centers & 378 \\
\hline A inaugurar em 2009 & 23 \\
\hline Total de Lojas & 65.500 \\
\hline Lojas Satélites & 63470 \\
\hline Lojas Âncoras & 2.030 \\
\hline Empregos Gerados (mil pessoas) & 720639 \\
\hline Faturamento 2008 (R\$ bilhões) & 64,6 \\
\hline Tráfego de pessoas (milhões por mês) & 325 \\
\hline Vendas em relação ao Varejo Nacional & $18,30 \%$ \\
\hline
\end{tabular}

Tabela 2: Grandes números: Brasil em Janeiro de 2009.

Fonte: ABRASCE. <www.portaldoshopping.com.br/sobreosetor.asp> Janeiro, 2009.

\begin{tabular}{|l|r|r|}
\hline \multicolumn{3}{|c|}{ Participação por região em 2009 } \\
\hline Norte & 9 & $2 \%$ \\
\hline Nordeste & 51 & 0,14 \\
\hline Centro-Oeste & 35 & $9 \%$ \\
\hline Sudeste & 209 & 0,55 \\
\hline Sul & 74 & $20 \%$ \\
\hline Total & 378 & 1 \\
\hline
\end{tabular}

Tabela 3: Participação por região em 2009.

Fonte: ABRASCE. <www.portaldoshopping.com.br/sobreosetor.asp> Janeiro, 2009.

\begin{tabular}{|c|c|c|c|c|c|}
\hline \multicolumn{6}{|c|}{ Evolução Shopping Centers 2000/2008 } \\
\hline Ano & $\begin{array}{l}\text { Número de } \\
\text { Shopping Centers }\end{array}$ & Lojas & \begin{tabular}{|l|} 
Faturamento em \\
milhões de reais
\end{tabular} & Empregos & $\begin{array}{l}\text { Tráfego de Pessoas } \\
\text { (milhões/visitas por mês) }\end{array}$ \\
\hline 2000 & 280 & 34.300 & 26.136 & 328.000 & 125 \\
\hline 2001 & 294 & 36.300 & 28.750 & 400.000 & 135 \\
\hline 2002 & 304 & 38.700 & 31.705 & 441.000 & 160 \\
\hline 2003 & 316 & 39.437 & 35.909 & 453.000 & 175 \\
\hline 2004 & 325 & 40.803 & 41.591 & 476.595 & 185 \\
\hline 2005 & 338 & 42.363 & 45.471 & 488.286 & 181 \\
\hline 2006 & 351 & 56.487 & 50.000 & 524.090 & 203 \\
\hline 2007 & 365 & 62.086 & 58.000 & 629.700 & 305 \\
\hline 2008 & 377 & 65.500 & 64.600 & 720.639 & 325 \\
\hline
\end{tabular}

Tabela 4: Evolução shopping centers 2000/2008.

Fonte: ABRASCE. <www.portaldoshopping.com.br/sobreosetor.asp> Janeiro, 2009.

Partindo para uma análise sobre o ano de 2008, o setor obteve um faturamento de $\mathrm{R} \$$ 64,4 bilhões, havendo um crescimento de $11 \%$ em relação ao ano anterior, este fato se deve também ao aumento no número de empreendimentos no ano que foi de 13 novos shoppings e que em 2009 estima-se a inauguração de mais 23 negócios (ABRASCE, 2009). 


\subsubsection{Organização da estrutura Física}

Como toda empresa atuante em conformidade com as leis ambientais, a estrutura do shopping sofreu algumas modificações para atender as exigências, tendo aspectos modificados na estrutura interna e externa, abrangendo áreas no qual circulam clientes e funcionários.

$\mathrm{Na}$ recepção do escritório administrativo do Pátio Brasil shopping são encontradas lixeiras de coleta seletiva de lixo, com orientações bem específicas, até fornecendo exemplos para cada tipo de material. Além disso, têm-se um posto de coleta de pilhas e baterias, folders e banners explicativos sobre alguns programas, como a coleta de lâmpadas fluorescentes. E por último ainda é posto em destaque um mural do meio ambiente, onde se tem as políticas ambientais do Grupo Sonae, assim como a cópia do certificado ISO 14001 que o shopping possui e outros dois pareceres sobre a qualidade da água e dos reservatórios utilizados pelo shopping. Este destaque à divulgação dos programas na própria administração se dá também no refeitório e é muito importante, por ser uma área de grande circulação interna dos funcionários das lojas e de apoio.

A área de descarte utilizada pelo shopping é organizada segundo as normas impostas pelos padrões ambientais, tendo áreas específicas para o descarte de cada tipo de material, assim como o depósito especial para produtos químicos e lubrificantes, coletores de resíduos junto aos geradores e mural com as políticas, e acompanhamento de indicadores, como o consumo de água e energia e o percentual de material reciclado pelo shopping.

Foi verificado que todas as lixeiras do shopping são preparadas com divisões para a realização da coleta seletiva do lixo, entretanto as mesmas não possuem informações suficientes para que o resultado seja realmente efetivo.

A arquitetura do prédio, principalmente no que se refere ao andar da praça de alimentação, sofreu estruturações para que aproveite ao máximo a luz natural, tendo neste andar, na área central o teto inteiramente de vidro assim como as paredes laterais sendo revestidas do mesmo material. Os sanitários do prédio possuem temporizadores em todos os seus equipamentos, objetivando com isso a redução no consumo de água. 


\subsubsection{Funcionários de apoio}

Abordando o grupo analisado dos funcionários de apoio, como o pessoal de limpeza, segurança e brigadistas, estes recebem treinamentos sobre as políticas ambientais, antes mesmo de iniciarem as suas atividades no shopping. Durante a pesquisa, procurou-se avaliar estes indivíduos através da observação e do questionamento de informações comuns, se passando por clientes habituais e levantando dúvidas corriqueiras que pudessem ser geradas pelos próprios clientes.

Através da observação, verificou-se que os próprios funcionários, algumas vezes não realizavam atividades simples como a separação do lixo no momento do descarte, principalmente em momentos do expediente, onde o volume de objetos a serem descartados era muito grande. Ao mesmo tempo, foi constado através da observação que os próprios clientes do shopping terminam por agir de duas formas devido a existência de lixeiras específicas para a coleta seletiva: terminam por deixar as bandejas nas mesas, aumento assim o fluxo de trabalho dos funcionários de limpeza; direcionam as bandejas ao lixo, mas as deixam em um depósito central entre os lixos sem realizar o seu efetivo descarte. O mesmo problema foi verificado com as lixeiras espalhadas pelo shopping, em que todas possuem áreas coletoras para cada tipo de material (papel, plástico, metal e orgânico), porém sem orientações específicas. O pesquisador atribui essa característica principalmente a falta de informação, pois as lixeiras apenas sinalizam o tipo de material, mas muitas vezes os clientes podem ficar em dúvida de qual lixeira seria a mais adequada para aquele determinado tipo de material.

Sugere-se que faça uma lista com os nomes dos objetos que são mais utilizados no shopping e que sejam fixadas placas adesivas com exemplos em cada lixeira, tendo ainda um quadro resumo de informações acima das mesmas, um bom exemplo desta orientação pôde ser constatado na própria recepção da parte administrativa do shopping, onde existem lixeiras de coleta seletivas bem identificadas e com excelentes orientações.

Quando o pesquisador se adentrou na etapa de questionamentos aos funcionários, verificou-se que os mesmos detinham o conhecimento mínimo necessário para orientar os clientes em qual lixeira o material específico deveria ser descartado. 


\subsubsection{Gerentes de lojas e restaurantes}

Como já citado na referência deste estudo, ao se implantar estratégias de responsabilidade social empresarial em uma empresa, alguns diretrizes devem ser lembradas, como a transparência das ações, valorização dos empregados, fazer sempre mais pelo meio ambiente, entre outros aspectos (INSTITUTO ETHOS, 2003). Estes pontos apesar de serem direcionados ao tema da RSE podem ser generalizados também a implantação da gestão ambiental, pois abordam a postura da empresa visto os seus agentes envolvidos, postura esta que deve ser adota não só como prática visto a adoção de um novo programa, mas ser incorporada como parte da cultura da empresa.

Um dos pontos verificados como sendo impactantes ao bom funcionamento de programas internos as empresas, é o grau de conhecimento dos stakeholders sobre o tema tratado, o nível de educação que estes têm acerca do assunto e a sua percepção de importância do mesmo. Dessa forma, foram estruturadas questões que identificassem estes pontos citados junto aos gerentes das lojas (o mesmo foi realizado com os gestores administrativos), tendo como resultado o baixo conhecimento sobre gestão ambiental e identificado como conheço ou não conheço muito bem o assunto abordado. Com relação a educação sobre o tema, a maioria destes nunca participaram de nenhum evento educativo, e ainda foi questionado sobre o grau de importância que os gerentes atribuem aos programas ambientais como forma de obtenção de vantagem competitiva, e estes apontaram como sendo importante em sua maioria absoluta. A partir disto, pode ser visualizado um ponto de oportunidade para a administração do shopping em adotar programas que relacionem mais os lojistas, visto que estes sabem da importância do tema, mas primeiro se faz necessária um maior investimento em educação sobre o assunto.

Outro fator determinante no sucesso da adoção de um programa em uma empresa se faz pela comunicação do mesmo aos agentes que pretende atingir, por isso foi questionado aos gerentes das lojas como estes avaliavam a comunicação realizada pelo shopping acerca dos programas ambientais. A maioria relativa apontou como sendo eficiente, mas se deve atentar ao fato de que a pesquisa obteve um percentual bem próximo com a classificação pouco eficiente. Nesta pergunta se identifica talvez um ponto com deficiência de atuação da administração e que poderia ser remodelada, visto a finalidade que a comunicação tem junto aos programas ambientais, mobilizando e envolvendo ainda mais os stakeholders, culminando no sucesso ou fracasso de algumas ações propostas. 
Visando identificar como se dá o nível de conhecimento a respeito dos programas ambientais já executados pelo shopping Pátio Brasil, assim como verificar quais destes programas afetam as atividades dos lojistas, foram elaboradas duas questões, a primeira sobre o grau de conhecimento e a segunda sobre os programas impactantes. Através destas questões, se levanta relações como o próprio grau de envolvimento dos lojistas com os programas executados, pois para a boa realização dos mesmos se faz necessário ter pelo menos o conhecimento, assim como se torna preocupante caso haja algum programa altamente impactante nas atividades, porém que os lojistas não tenham um grau de conhecimento sobre o mesmo.

Após análise, foi identificado que quatro programas ambientais realizados pelo shopping possuem um percentual de maioria absoluta com um nível de conhecimento abaixo do patamar não conheço muito bem, todavia, estes mesmos programas foram identificados como não sendo impactantes nas atividades dos lojistas. Procurando ainda comparar os dados obtidos nas duas questões, verifica-se que os programas considerados como de maior impacto às atividades, os de recolhimento de pilhas e baterias, coleta seletiva de lixo e controle de água e energia, ao mesmo tempo obtiveram resultados positivos em relação ao grau de conhecimento, todos estes obtendo mais de $70 \%$ da amostra com pelo menos o grau conheço de conhecimento.

Por último, ainda buscou-se através de uma questão aberta, identificar sugestões de melhorias aos programas atuais ou novas idéias que pudessem gerar benefícios ao shopping junto à questão da gestão ambiental. De maneira geral, o ponto mais abordado foi a questão da realização de palestras para funcionários e clientes que visem a disseminação de conhecimento acerca da gestão ambiental, porém ao mencionar esta questão à administração do shopping, foi verificado que existe um cronograma com treinamentos sobre o assunto, mas o número de lojistas que se prontificam a participar dos mesmos é muito baixo. Além desta proposta foram mencionadas idéias para a realização de programas envolvendo a reciclagem de garrafas PET e sacolas plásticas, podendo haver neste caso alguma promoção junto às lojas que incentivassem os clientes a aderir às campanhas e gerassem benefícios a todos.

\subsubsection{Gestores administrativos do Shopping Pátio Brasil}

Através dos questionários, buscou-se primeiramente identificar o nível de conhecimento dos gestores administrativos acerca do tema gestão ambiental, onde foi 
identificado que todos conhecem bem o tema e já participaram de treinamentos oferecidos pelo próprio Grupo Sonae. Esta pergunta ganha uma importância ainda maior se a interpretarmos a partir da idéia de que independente da área no qual o gestor atue, tendo metas diretas a sua área ou não, se faz necessário que este tenha um bom grau de conhecimento acerca do tema, obtendo dessa forma um maior envolvimento de todas as áreas, podendo sempre que possível contribuir com sugestões. Esta característica vem em acordo com a própria estrutura organizacional da empresa, onde não existe um setor específico que cuide de todos os aspectos ligados a gestão ambiental e por isso o controle e execução de atividades ligadas ao tema ficam fragmentadas pela administração.

Quando questionado se as áreas em que atuam possuem alguma meta ambiental específica, as áreas administrativas e de auditoria identificaram como não tendo, porém ao mesmo tempo identificam na questão subseqüente alguns programas realizados pelo shopping e que impactam diretamente em suas atividades de trabalho. Tendo nestas duas áreas especificamente o monitoramento periódico para análise de qualidade do ar, da água e efluentes e os eventos de consciência ambiental para lojistas e consumidores pela auditoria, já para a área administrativa os programas de atuação em conformidade com a legislação e normas ambientais, o controle do consumo de água e energia, a utilização de papel reciclável em todo o material de expediente, a reciclagem de lâmpadas para a retirada de substâncias tóxicas, o monitoramento periódico para análise de qualidade do ar, da água e efluentes, os eventos de consciência ambiental para lojistas e consumidores e a decoração de natal ecologicamente correta, foram caracterizados como impactantes à área.

Visando identificar quais são os stakeholders que influenciaram a administração do shopping a adotar a práticas da realização de ações ambientais, todos os gestores foram unânimes em dizer que esta ação veio em decorrência do Grupo Sonae. Esta questão é bem interessante pelo fato de que os gestores poderiam marcar quantas alternativas desejassem e foram listados os stakeholders, governo, mídia, clientes do shopping, funcionários, lojistas, Grupo Sonae e um campo para outros, considerados estes como sendo de grande influência na adoção de práticas ambientais em outras empresas, porém somente a alternativa do Grupo Sonae foi utilizada. Portanto, um dos objetivos de identificar através destes gestores a motivação que os levaram a adotar práticas ambientais, terminou por gerar um resultado enviesado, sabendo que estes devem seguir as políticas de uma matriz gerencial. 
Os temas da Gestão Ambiental, Responsabilidade Social Empresarial e Desenvolvimento Sustentável apresentam pontos bastante conexos tendo muitas vezes na literatura um assunto sendo bastante mencionado na explicação e citação do outro. Aspectos como a adoção de projetos sociais com o objetivo do próprio complemento de programas ambientais precisam ser identificados e geram benefícios maiores ainda à empresa executora (INSTITUTO ETHOS, 2003). Através desta linha conhecimento, buscou-se identificar se existem programas sociais beneficiados pelas ações ambientais realizadas pelo shopping, e neste aspecto foi identificado somente o programa adote uma nascente, programa este em que o shopping juntamente com o governo do Distrito Federal e órgãos responsáveis, realizaram a "adoção" de um berço d’água localizado no Riacho Fundo, onde o shopping disponibiliza recursos para a sua preservação.

\subsection{Uso de tabelas e gráficos ou, ainda, estatísticas}

O perfil da amostra de gerentes ficou caracterizada como sendo de $66 \%$ do gênero feminino, $50 \%$ com idade entre 18 a 25 anos, $44 \%$ trabalhando no shopping a mais de 2 anos e $22 \%$ entre 1 e 2 anos, e por último $60 \%$ com nível médio de escolaridade, dados estes que podem ser verificados nos gráficos a seguir:

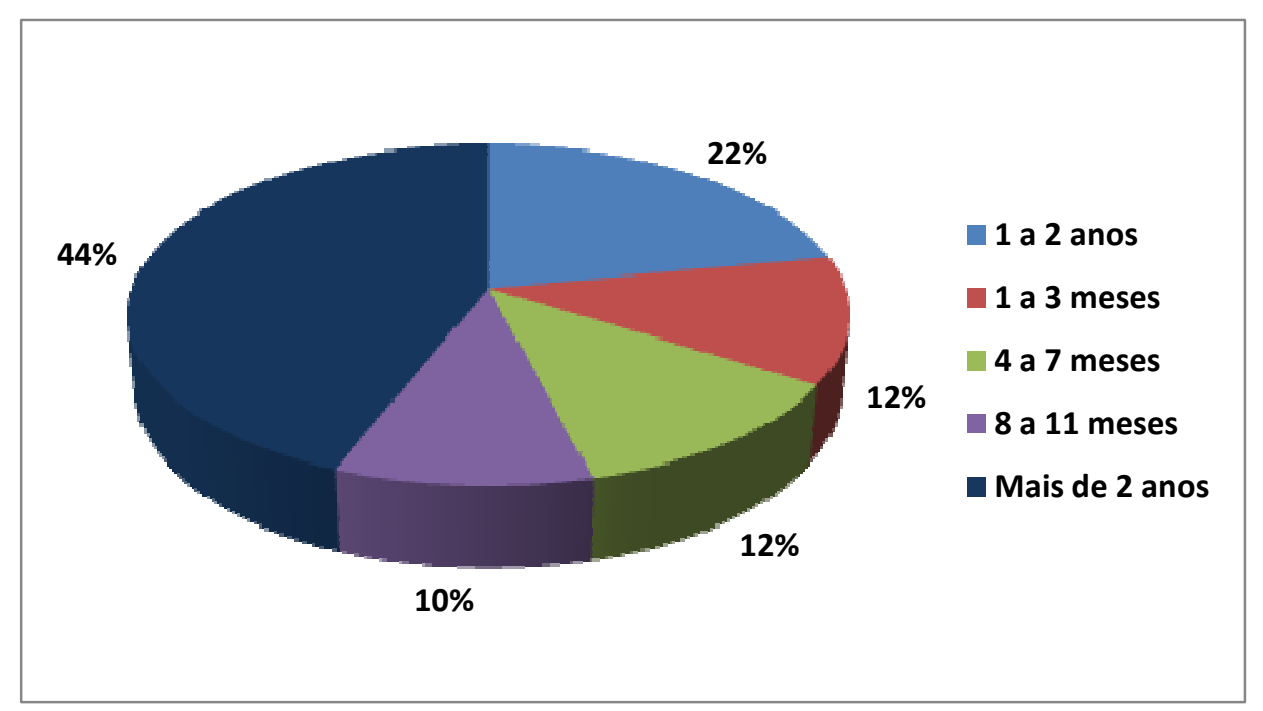

Figura 3: Tempo de serviço - Gerentes de loja.

Fonte: Autoria própria. 


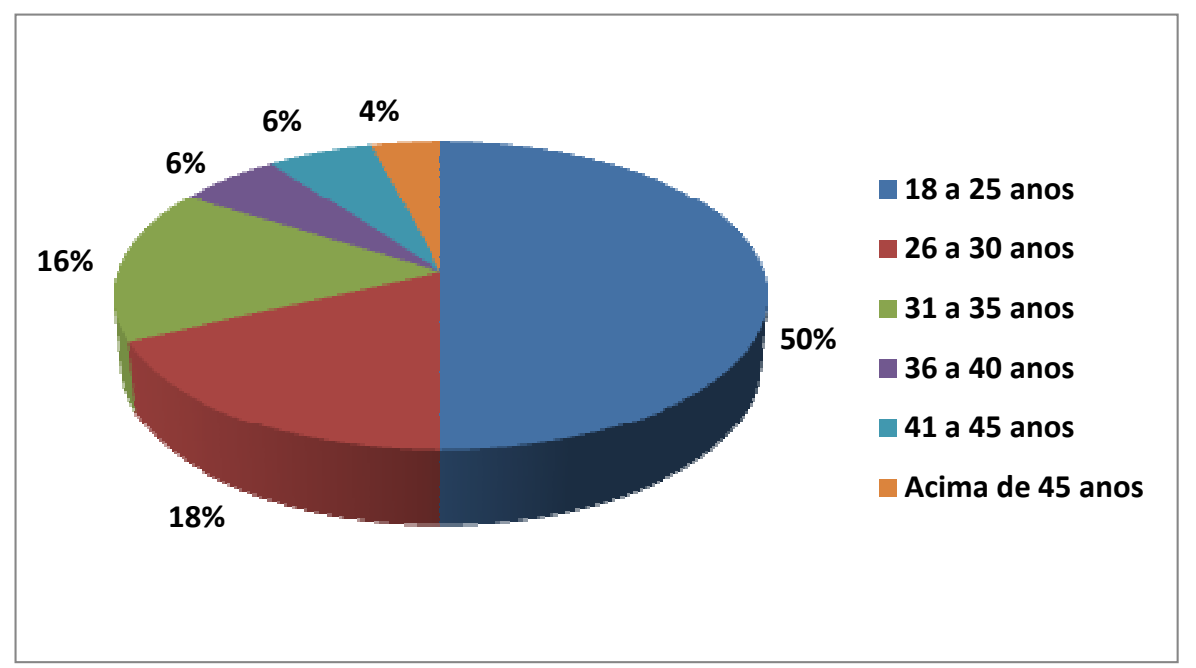

Figura 4: Idade - Gerentes de loja.

Fonte: Autoria própria.

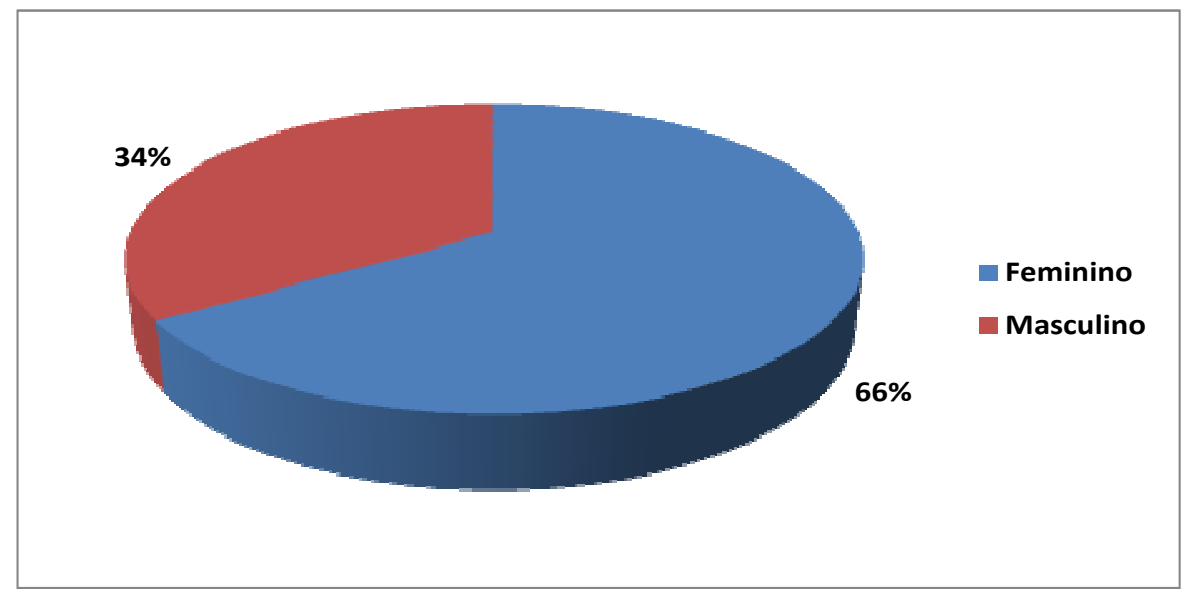

Figura 5: Gênero - Gerentes de loja.

Fonte: Autoria própria.

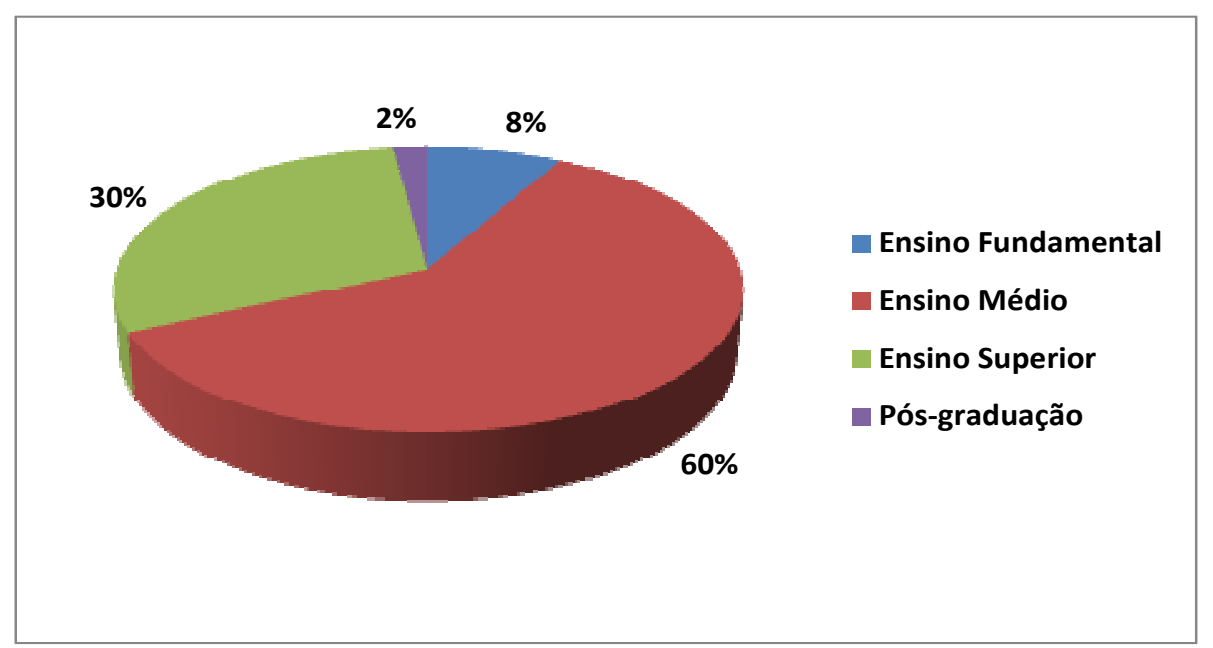

Figura 6: Nível de escolaridade - Gerentes de loja.

Fonte: Autoria própria. 
O questionário utilizado com os gerentes das lojas tinha como objetivo verificar o nível de conhecimento destes funcionários acerca do tema de gestão ambiental, assim como o grau de relação dos programas realizados pelo shopping e o impacto destes nas atividades dos gerentes. As informações coletadas também servirão de base para comparação entre a percepção dos programas a partir destes agentes com a visão das ações pela própria administração do shopping.

Tendo como objetivo verificar a familiaridade dos gerentes das lojas com o tema da gestão ambiental, foi questionado a eles o grau de conhecimento acerca do tema, e verificouse que apesar de $46 \%$ dos entrevistados classificarem como tendo conhecimento do assunto, se obteve um percentual de $34 \%$ bastante considerável que aponta que não conhece muito bem o tema, dados estes que são apresentados no gráfico a seguir:

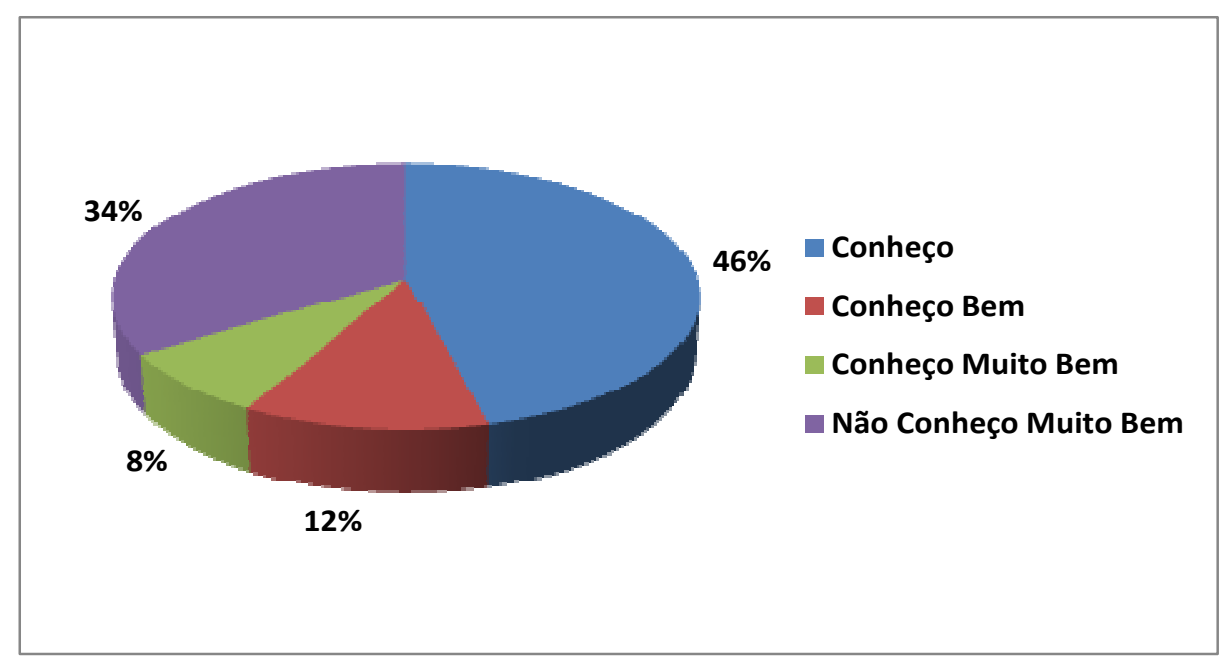

Figura 7: Grau de conhecimento acerca do tema Gestão Ambiental - Gerentes de loja.

Fonte: Autoria própria.

Buscando ainda complementar a questão anterior, foi levantado o percentual de gestores que já realizaram algum tipo de treinamento ou palestra sobre o tema (figura 8) e $88 \%$ dos entrevistados falaram que nunca participaram, um número bastante expressivo e que pode ser base para justificar a falta de conhecimento identificada na questão 1 , além de identificar talvez um foco onde o shopping precisa estar mais atuante para garantir a colaboração de seus funcionários e a efetividade de seus programas. É importante salientar que com o aumento do conhecimento acerca do tema, além da integração de outras medidas complementares, como bônus ou punições aos colaboradores que não cumprirem as políticas ambientais, o desempenho alcançado será muito mais significativo. Uma observação 
interessante é que apenas $2 \%$ dos entrevistados apontaram que participaram de treinamentos oferecidos pelo próprio shopping.

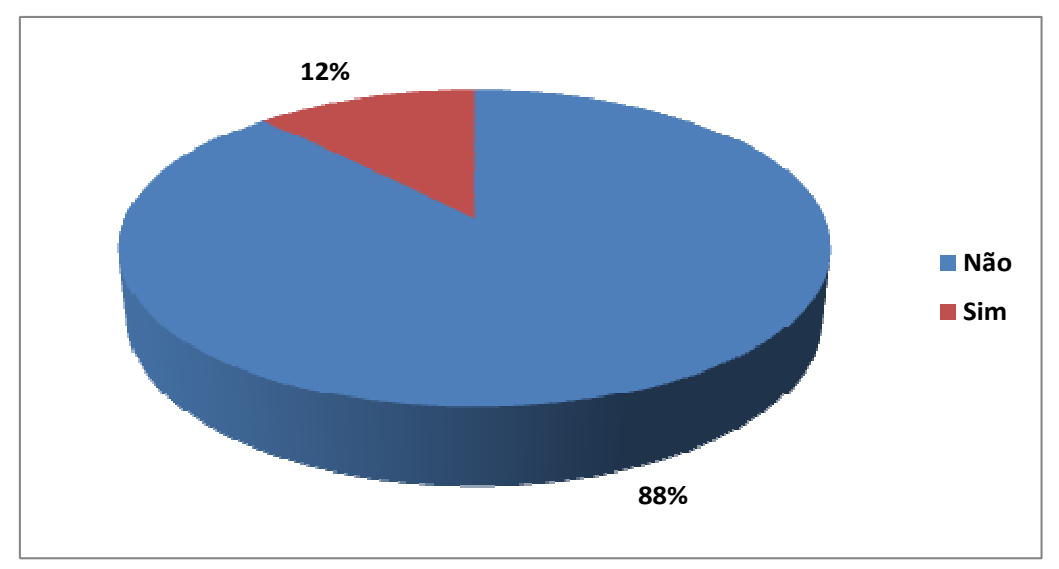

Figura 8: Já realizou algum treinamento acerca do tema Gestão Ambiental? - Gerentes de loja.

Fonte: Autoria própria.

Outra questão muito importante acerca dos programas ambientais que estão sendo realizados é saber como é a percepção dos agentes envolvidos sobre o tema e se estes vêm as ações traçadas como forma de obter vantagem competitiva. Esta questão pode ser claramente influenciada pelo grau de conhecimento dos envolvidos acerca do tema, pois em algumas situações, estes podem considerar o tema sem importância e que não gera benefícios em relação a concorrência apenas pelo fato de não o conhecer muito bem. Porém, no shopping Pátio Brasil 88\% dos entrevistados (figura 9) consideram o tema de importante a extremamente importante como forma de obtenção de vantagem competitiva, ponto muito positivo que mostra que a administração do shopping talvez tenha um nível de colaboração destes indivíduos ainda maior por estarem cientes da importância do tema e de suas ações, como aborda North (1997) como sendo fonte de benefícios principalmente estratégicos para as organizações. 


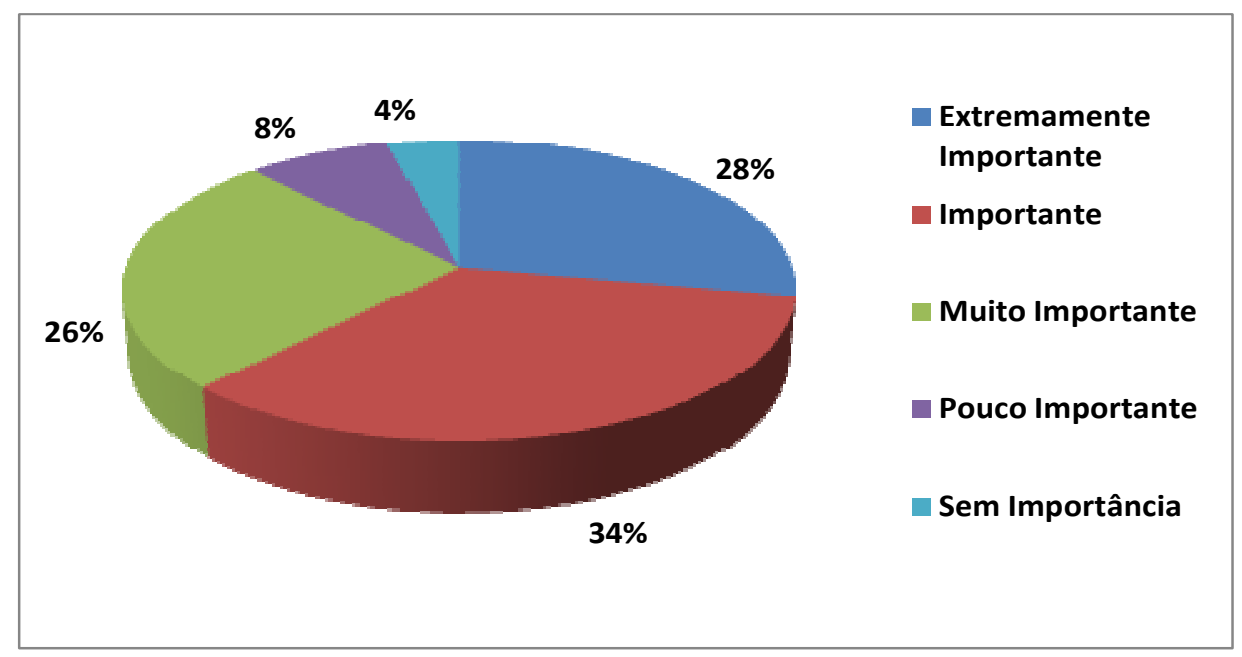

Figura 9: Grau de importância do tema gestão ambiental como obtenção de vantagem competitiva - Gerentes de loja.

Fonte: Autoria própria.

Para que uma política ambiental proposta se torne efetiva, um dos pontos mais importantes é traçar um plano eficiente de comunicação com seus envolvidos (DONAIRE, 2003). Por isso, foi questionado aos gerentes de lojas, como estes consideram a comunicação do shopping acerca dos programas ambientais. Estes foram questionados em uma escala de ineficiente a extremamente eficiente, onde $46 \%$ dos entrevistados a classificaram como sendo eficiente e $32 \%$ como sendo pouco eficiente (figura 10). Com esta constatação se pode observar um ponto de oportunidade a ser explorado, aumentando a comunicação acerca dos programas, para torná-los mais efetivos, mas ao mesmo tempo se faz importante comparar este resultado com o grau de conhecimento e importância atribuído ao tema, pois com uma comunicação mais efetiva, provavelmente ambas perguntas teriam respostas mais positivas.

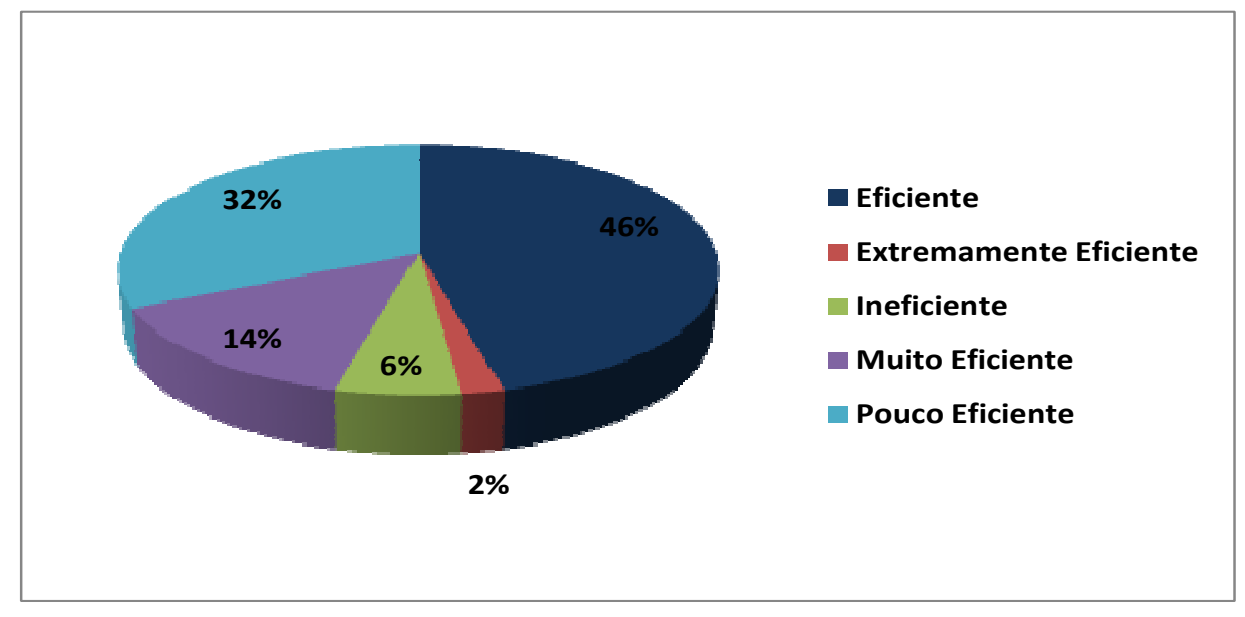

Figura 10: Comunicação dos Programas Ambientais - Gerentes de loja.

Fonte: Autoria própria. 
Através da lista de programas ambientais realizadas pelo shopping, foi questionado aos entrevistados o grau de conhecimento sobre estas ações (figura 11), e verificou-se que grande parte dos gerentes de lojas apenas tem conhecimento sobre o que está sendo tratado, mas desconhecem maiores detalhes acerca dos mesmos. Este questionamento acerca do grau de conhecimento dos programas, ainda mostra informações como 52\% dos entrevistados não conhecem ou não conhecem muito bem a atuação do shopping em conformidade com a legislação legal, não havendo desta forma um destaque maior para a certificação ISO 14001 obtida. Para alguns dos programas é bastante justificável a falta de conhecimento ou apenas conhecimento do mesmo, pois existem programas que, por exemplo, são afetos apenas a restaurantes, e por isso ainda foi levantado com esta mesma lista de programas, quais destes os gerentes consideram como impactantes as suas atividades, tendo apenas os programas de consumo de água e energia, além do de coleta de lixo com valores iguais ou maiores a 50\% dos entrevistados, como pode ser observado na figura 12 a seguir:

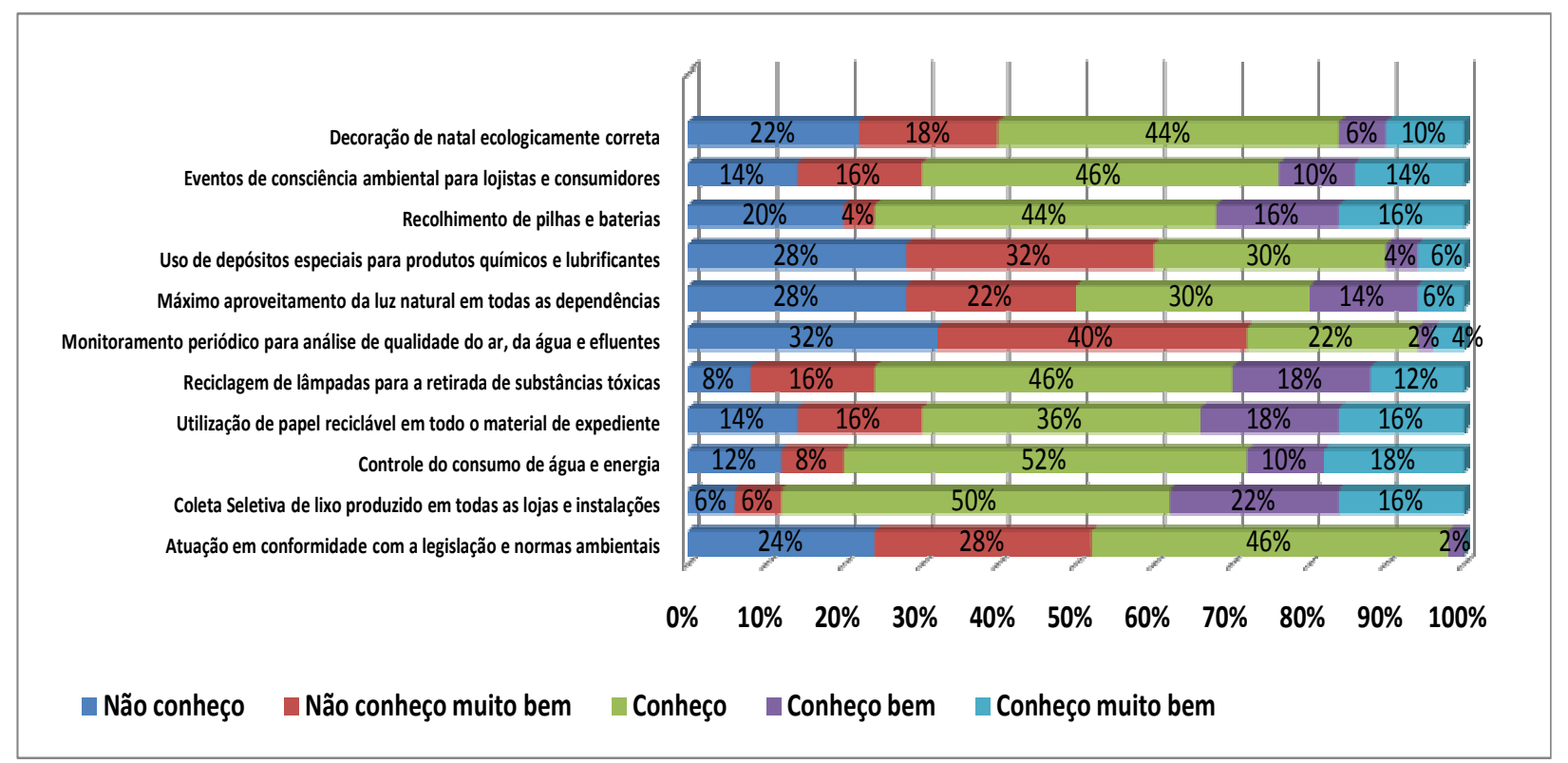

Figura 11: Grau de conhecimento acerca dos programas ambientais realizados pelo shopping - Gestores de loja. Fonte: Autoria própria. 


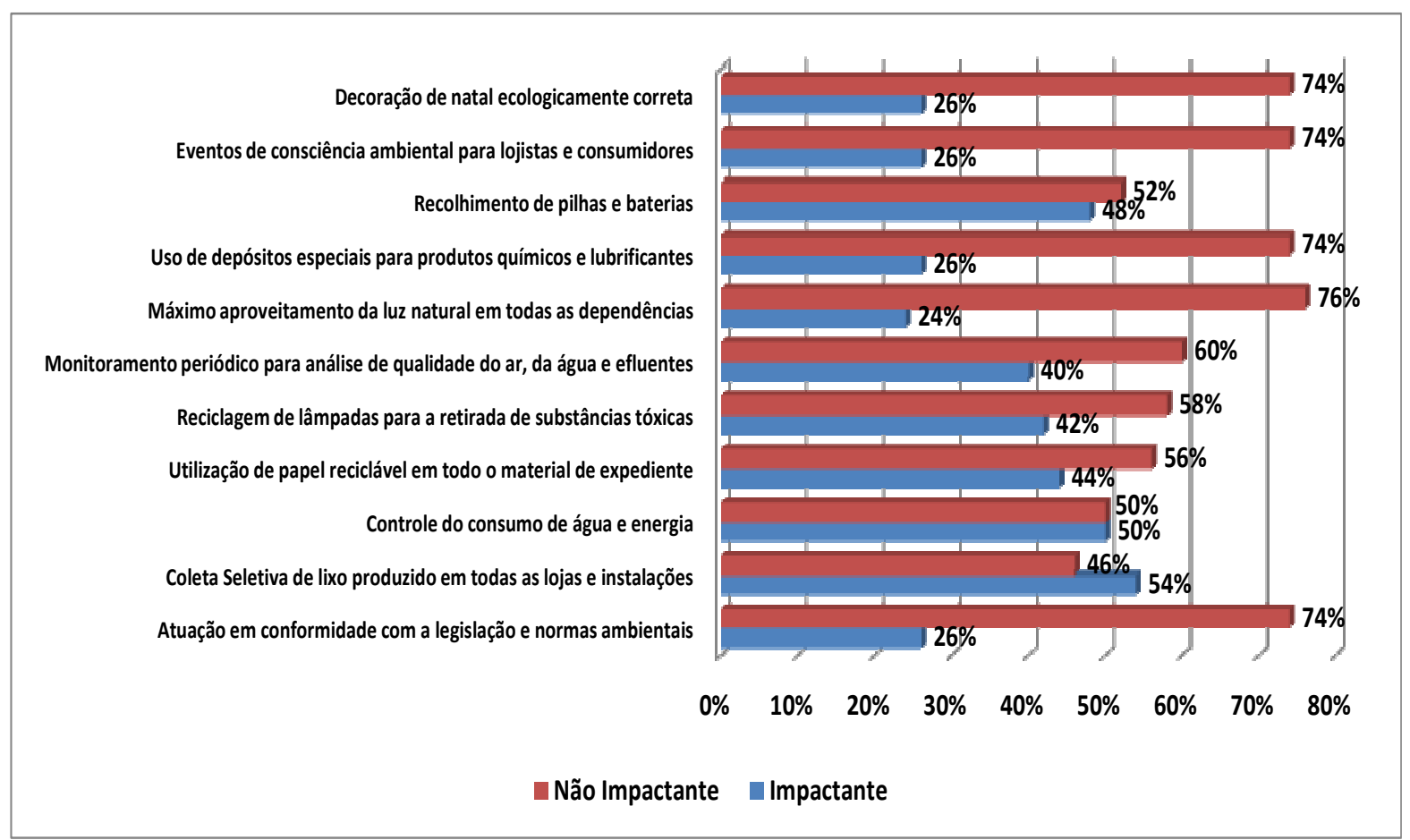

Figura 12: Grau de impacto dos programas ambientais sobre as atividades desenvolvidas - Gerentes de loja. Fonte: Autoria própria.

A amostra obtida com os gerentes administrativos do shopping Pátio Brasil é composta por gestores de Marketing, Administrativo, Operações, Auditoria e Superintendência e que têm seu perfil descrito através da tabela 5 apresentado a seguir:

\begin{tabular}{|l|l|l|l|l|l|}
\hline & Superintendência & Auditoria & Marketing & Administrativo & Operacional \\
\hline Idade & 18 a 25 anos & 26 a 30 anos & Acima de 45 anos & Acima de 45 anos & 31 a 35 anos \\
\hline Gênero & Feminino & Masculino & Masculino & Masculino & Masculino \\
\hline Grau de Escolaridade & Ensino Superior & Ensino Superior & Pós-graduação & Pós-graduação & Pós-graduação \\
\hline Tempo de trabalho no shopping & Mais de 2 anos & 1 a 2 anos & Mais de 2 anos & Mais de 2 anos & 1 a 2 anos \\
\hline
\end{tabular}

Tabela 5: Perfil da amostra de Gerentes Administrativos.

Fonte: Autoria própria.

Buscando identificar os benefícios que vêm sendo alcançados pelo shopping em termos estratégicos, operacionais e de receita, foi perguntado aos gerentes, segundo a percepção dos mesmos, quais dos benefícios apontados em uma lista e citados por North (1997) que o shopping já alcançou com as suas ações ambientais, e a tabela 6 abaixo apresenta os pontos levantados: 


\begin{tabular}{|l|r|}
\hline Benefícios alcançados & Frequência de citações \\
\hline Melhor adequação aos padrões ambientais & 5 \\
\hline Melhoria da imagem institucional & 5 \\
\hline Melhores relações com órgãos públicos, comunidade e grupos ambientalistas & 3 \\
\hline Economia de custos & 3 \\
\hline Maior comprometimento por parte da força de trabalho e melhor relacionamento com os empregados & 2 \\
\hline Acesso garantido a novos mercados & 1 \\
\hline
\end{tabular}

Tabela 6: Benefícios alcançados com os programas ambientais - Gerentes Administrativos.

Fonte: Autoria própria.

Dessa forma pode-se até identificar o porquê de algumas estratégias traçadas para o tema de gestão ambiental do shopping, visto que o foco da empresa em primeiro lugar sempre esteve ligado ao recebimento da certificação ISO 14001 e de melhorar a imagem institucional. Porém estas metas traçadas são ao mesmo tempo identificadas pelo questionário, que sofrem uma forte influência do grupo SONAE, tendo todos os gestores respondido como sendo alta esta influência, ou seja, o foco de direcionamento principal das ações ambientais da empresa não podem ser desvirtuadas do plano de políticas traçadas pelo grupo. 


\section{CONSIDERAÇÕES FINAIS}

Como já citado em diversas partes deste estudo, os temas da gestão ambiental, RSE e desenvolvimento sustentável, têm ganhado uma força cada vez maior nas últimas décadas, isto decorrente em grande parte da própria mudança na mentalidade da população mundial e surgimento de estudos acerca do uso descontrolado dos recursos naturais. Fatores como a educação dos indivíduos e a postura da empresas exploradoras destes recursos são determinantes para que haja mobilizações e readequações na forma de trabalho, mas para isso se faz necessário que as pessoas envolvidas acreditem realmente nos benefícios que tais ações podem vir a gerar.

Dependendo do segmento em atuação de determinada empresa, a estrutura organizacional da mesma pode ser determinante na condução de projetos ambientais. Entretanto no setor analisado de shopping centers, foi verificado que empresas do setor já possuem certa peculiaridade em sua formação estrutural, possuindo áreas bem enxutas e voltadas para o atendimento de necessidades mais corriqueiras e extremamente administrativas. Através do estudo foi verificado que pela não existência de uma estrutura ampla, as ações que de certa forma seriam direcionadas a áreas específicas como recursos humanos e mesmo uma área de gerência ambiental, são distribuídas por entre os setores. As gerências que possuem uma maior proximidade com a operacionalização da atividade, terminam por ficar responsáveis pelo controle e execução das mesmas. Pela própria revisão da literatura acerca deste assunto, verifica-se que a existência de uma área específica para a condução de todos os processos sobre a gestão ambiental, não se faz necessário dependendo do segmento, e este fato pode ser observado no shopping analisado, porém algumas atividades teriam uma maior efetividade se contasse com o aval de uma área direcionada ao tema.

Através do estudo, buscou-se ainda identificar pela ótica dos agentes envolvidos nos processos, os diversos fatores que influenciam a administração de uma empresa que realiza ações de gestão ambiental, RSE e desenvolvimento sustentável. Verifica-se que pontos como a comunicação, nível de envolvimento, comprometimento e conhecimento dos agentes afetados, estrutura gerencial dos programas, além de incentivos indiretos para efetuar o apoio aos programas e exigência dos clientes (consumidores externos) são fatores que impactam diretamente na condução de estratégias e políticas ambientais, necessitando da estruturação de um plano de ação para que se realize ações interligadas destes aspectos. 
Buscando ainda um maior esclarecimento sobre os fatores mencionados, verificou-se pela pesquisa que a maior parte dos programas realizados pelo shopping necessitava de um grande apoio dos lojistas, porém ao mesmo tempo estes não detinham um conhecimento muito claro acerca dos mesmos. Através deste ponto identificado, assim como a avaliação realizada sobre a comunicação, constata-se uma deficiência no processo e que impacta diretamente nos resultados finais das metas. Um ponto a se considerar, é que neste tipo de segmento a administração não conta com aparatos punitivos que obrigassem os lojistas a participarem dos treinamentos e palestras oferecidas, e por conta disto o coro presente a estas atividades é pouco representativo, o que perpetua esta falta de conhecimento sobre o tema. $\mathrm{O}$ interessante é constatar que ao mesmo tempo em que os treinamentos são oferecidos pela administração sem ter uma adesão representativa, foi identificado através da pesquisa que os lojistas sentem a necessidade de palestras, talvez esteja havendo uma falha na divulgação das atividades ou necessidade de reestruturação da proposta de treinamento, analisando melhores dias e horários para atender a um grande número de colaboradores.

Apesar da administração não dispor de recursos que obriguem os lojistas a participarem das atividades de caráter educacional, estes devem seguir a políticas de meio ambiente definidas por contrato, e com possibilidade de serem multados caso não cumpram com as determinações do shopping. Esta ação se mostra muito efetiva e que serve de sugestão a outras empresas do setor que pretendem implantar programas ambientais, definindo em contrato ações a serem seguidas pelos lojistas e que dão apoio aos programas executados.

As empresas atuantes no segmento de shopping centers e que procuram adotar práticas ambientais em suas organizações, devem inicialmente procurar identificar o perfil dos agentes com o qual irão lidar, identificando o nível de conhecimento acerca do tema, assim como desenvolver um plano de comunicação eficiente que consiga de forma efetiva a divulgação de informações sobre as ações que estão sendo planejadas. Como os programas traçados serão ações de caráter permanente, estes não podem ser gerenciados com uma estrutura de projeto, onde caracterizaria algo com começo, meio e fim e objeto único a ser realizado, mas devem ser incorporados ao fluxo de trabalho das áreas tendo previamente definido um plano de responsabilidades que devem ser monitorados e cobrados por uma área gerencial.

Visto que se trata de um segmento onde os lojistas somente verão os benefícios de se alocar parte de seu tempo para a dedicação a atividades ligadas aos programas ambientais, caso haja um retorno real aos clientes e como conseqüência aumento nas vendas, a 
administração dos shoppings deveriam analisar no momento de estruturar um programa se este é compatível com alguma campanha de marketing, visto que um dos objetivos principais da gestão ambiental é comunicar o que se está fazendo a fim de criar uma vantagem competitiva frente aos concorrentes. Esta divulgação termina por mostrar ao cliente final o diferencial da organização em estar se dispondo de recursos para atuar em seus fluxos de trabalho, mas de maneira responsável e protegendo o meio ambiente e a sociedade. A geração de bônus aos clientes que contribuírem com as campanhas poderia ser uma proposta de campanha que aumentaria o envolvimento dos lojistas e ao mesmo tempo melhoraria a imagem do shopping, criando um maior fluxo de clientes e aumento nas vendas. Estes bônus poderiam ser um simples vale estacionamento a cupons de descontos a serem utilizados nas lojas.

Uma característica verificada foi o impacto que a implantação destes programas tiveram à administração do shopping, e verifica-se que as áreas tiveram que modificar rotinas em virtude das ações traçadas, tendo que desenvolver planos para o atingimento dos resultados almejados. Dessa forma, pôde-se constatar o alto impacto que estas ações tiveram na parte administrativa da empresa.

Além dos fatores que impactam a administração, foi pesquisado os benefícios que uma empresa do setor de shopping center teria com a implantação de ações voltadas ao tema da gestão ambiental. Através do estudo, verificou-se que além da economia de custos geradas, como a redução no consumo de água e energia, as ações desenvolvidas terminam por gerar benefícios junto a melhoria da imagem institucional, assim como o estreitamento do relacionamento com os agentes externos.

Ainda se buscou identificar os motivos que levaram o shopping a adotar uma postura sócio-ambiental correta, mas por características específicas da empresa sob análise de ser uma filial administrativa de um grupo gestor de shopping centers, esta constatação ficou prejudicada. Foi visto que o shopping é direcionado a atuar em determinados campos da gestão ambiental, visto as determinações encontradas no plano de políticas ambientais do Grupo Sonae Sierra, e por isso não foi possível realizar o levantamento do impacto de agentes como o governo, Ongs e outros sobre a implantação de medidas ambientais em empresas do setor de shopping centers. 


\section{REFERÊNCIAS}

ALMEIDA, J. R.; MELlO C. S.; CAVAlCANTI Y. Gestão Ambiental - Planejamento, Avaliação, Implantação, Operação e Verificação. Rio de Janeiro: Ed. Thex, 2 ed., 2004.

ASSOCIAÇÃO BRASILEIRA DE SHOPPING CENTERS. Desempenho da indústria de Shopping Centers no Brasil. Disponível em: <http://www.portaldoshopping.com.br/sobreosetor.asp?codAreaMae=10\&codArea=13\&codC onteudo=1>. Acesso em: 03 abr. 2009.

BACKER, P. Gestão ambiental: A administração verde. Rio de Janeiro: Ed. Qualitymark, 1 ed., 1995.

BARBETTA, P. A. Estatística Aplicada às Ciências Sociais. Editora da UFSC. Florianópolis, 2002.

BRANDALIZE, L. T. Modelos de medição de percepção e comportamento: Uma revisão. In: Laboratório de Gestão, Tecnologia e Informação - UFSC, Florianópolis, 2005.

COLLIS, J; HUSSEY, R. Pesquisa em Administração - um guia prático para alunos de graduação e pós-graduação. Porto Alegre: Ed. Bookman, 2 ed., 2005.

CONAMA - Conselho Nacional do Meio Ambiente. Resolução no 001, de 23 de janeiro de 1986, publicado no $\quad D$ n $O$ O $\quad$ U. <www.mma.gov.br/por/conama/res/res/86/res0186.html> Acesso em 03 jun. 2002.

CONRADO, D. Recuperação e preservação do meio ambiente - uma oportunidade de geração de empregos através das inovações tecnológicas. 2000. Dissertação (Mestrado Profissionalizante em Administração de recursos humanos) - Pós-Graduação em Administração, UFRGS, Porto Alegre.

CORAZZA, R. I. Gestão Ambiental e mudanças da estrutura organizacional. RAE eletrônica, v. 2, n. 2, p. 119-30, jul./dez. 2003.

DONAIRE, D. Gestão ambiental na empresa. São Paulo: Ed. Atlas, 2 ed., 1999.

GRUPO SONAE SIERRA. Portal Ambiente. Disponível em: <http://www. http://www.ambiente.sonaesierra.com/Public/Normal/pt-PT/paginaprincipal.aspx >. Acesso em: 03 abr. 2009.

GUMERATO, H. B. A competitividade da empresa que preserva o ambiente. 2003. Dissertação (Mestrado em Economia) - Universidade de Brasilía, Distrito Federal.

IBGE. Indicadores de Desenvolvimento Sustentável. Rio de Janeiro, 2008.

INSTITUTO ETHOS E RESPONSABILIDADE SOCIAL. Responsabilidade Social Empresarial para Micro e Pequenas Empresas. São Paulo, 2003. 
KRAEMER, M. E. P. Gestão Ambiental: Um Enfoque no Desenvolvimento Sustentável. Gestãoambiental, Itajai/SC, mar. 2004. Disponível em: <http://www.gestaoambiental.com.br/kraemer.php>. Acesso em: 16 mar. 2009.

MAIMON, D. Eco-estratégia nas empresas brasileiras: realidade ou discurso? RAE Revista de Administração de Empresas, v. 34, n. 4, p. 119-30, jul./ago. 1994.

MALHOTRA, N. K. Pesquisa de Marketing: Uma orientação aplicada. Porto Alegre: Ed. Bookman, 4 ed., 2006.

MEYER, M. M. Gestão ambiental no setor mineral: um estudo de caso. p. 32, 2000. Dissertação (Mestrado em Engenharia da Produção) - Universidade Federal de Santa Catarina, Florianópolis.

MOREIRA, M. S. Estratégia e Implantação do Sistema de Gestão Ambiental (Modelo ISO 14000). Belo Horizonte: Ed. IDG, 2 ed., 2001.

NORTH, K. Environmental Business Management: An Introduction. 2. ed. Geneva: International Labour Office, 1997.

OLIVEIRA, G. B.; LIMA, J. E. S. O desenvolvimento sustentável em foco: uma contribuição multidisciplinar. São Paulo: Ed. Annablume, 1 ed., 2006.

PÁTIO BRASIL SHOPPING. Meio Ambiente. Disponível em: <http:// http://www.patiobrasil.com.br/ambiente.php>. Acesso em: 03 abr. 2009.

PORTER, M. E.; KRAMER, M. R. Estratégia e sociedade: o elo entre vantagem competitiva responsabilidade empresarial social. Harvard Business Review, n. 12, 2006.

ROSE, R. A Gestão Empresarial e a Questão Ambiental. Reciclagem.net, São Paulo, mar. 2003. Disponível em: <http:// www.compam.com.br/ricardo.htm>. Acesso em: 18 mar. 2009.

SACHS, I. Desenvolvimento includente, sustentável, sustentado. Rio de Janeiro: Ed. Garamond, 1 ed., 2004.

SANCHES, C. S. Gestão ambiental proativa. Revista de Administração de Empresas, v. 40, n. 1, p.76- 87, 2000.

VALLE, C. E. Qualidade Ambiental ISO 14000. Editora SENAC. 5a. Edição revista e ampliada, São Paulo, 2002.

VIEIRA, V. As tipologias, variações e características da pesquisa de marketing. Rev. FAE, Curitiba, v.5, n.1, p.61-70, jan./abr. 2002. 


\section{APÊNDICES}

\section{Apêndice A: Questionário - Gerentes das lojas}

Prezado entrevistado (a),

Este questionário faz parte de uma pesquisa sobre as políticas ambientais de empresas atuantes no setor de shopping centers. As informações obtidas serão utilizadas em uma monografia de graduação do curso de administração de empresas da Universidade de Brasília - UnB.

O questionário levará aproximadamente 5 minutos do seu tempo. Não há respostas certas ou erradas. Suas informações permanecerão em sigilo e não permitirão sua identificação individual. Por favor, leia atentamente as questões até o final e responda com cuidado. Desde já, obrigado pela colaboração.

1) Como o senhor(a) classificaria o seu grau de conhecimento acerca do tema gestão ambiental?
( ) Não conheço
( ) Não conheço muito bem
( ) Conheço bem
( ) Conheço
( ) Conheço muito bem

2) O senhor(a) já fez algum treinamento sobre gestão ambiental? Se sim, qual foi a empresa pelo qual o treinamento foi realizado?
( ) Não
( ) Sim. Qual?

3) Qual o grau de importância que o senhor(a) atribui a ações ambientais realizadas por empresas atuantes no setor de shopping centers como forma de obtenção de vantagem frente aos concorrentes?
( ) Sem importância
( ) Pouco importante
( ) Muito importante
( ) Importante
( ) Extremamente importante

4) Abaixo é apresentada uma lista com os programas realizados pelo shopping, marque ao lado de cada programa a opção que melhor reflete o seu grau de conhecimento:

\begin{tabular}{|l|l|l|l|l|l|l|}
\hline & Programas ambientais & $\begin{array}{l}\text { Não } \\
\text { conheço }\end{array}$ & $\begin{array}{l}\text { Não } \\
\text { conheço } \\
\text { muito } \\
\text { bem }\end{array}$ & Conheço & $\begin{array}{l}\text { Conheço } \\
\text { bem }\end{array}$ & $\begin{array}{l}\text { Conheço } \\
\text { muito } \\
\text { bem }\end{array}$ \\
\hline 1 & $\begin{array}{l}\text { Atuação em } \\
\text { conformidade com a } \\
\text { legislação e normas } \\
\text { ambientais }\end{array}$ & $\begin{array}{l}\text { Coleta Seletiva de lixo } \\
\text { produzido em todas as } \\
\text { lojas e instalações }\end{array}$ & $\begin{array}{l}\text { Controle do consumo de } \\
\text { água e energia }\end{array}$ & & & \\
\hline 4 & $\begin{array}{l}\text { Utilização de papel } \\
\text { reciclável em todo o }\end{array}$ & & & & & \\
\hline
\end{tabular}




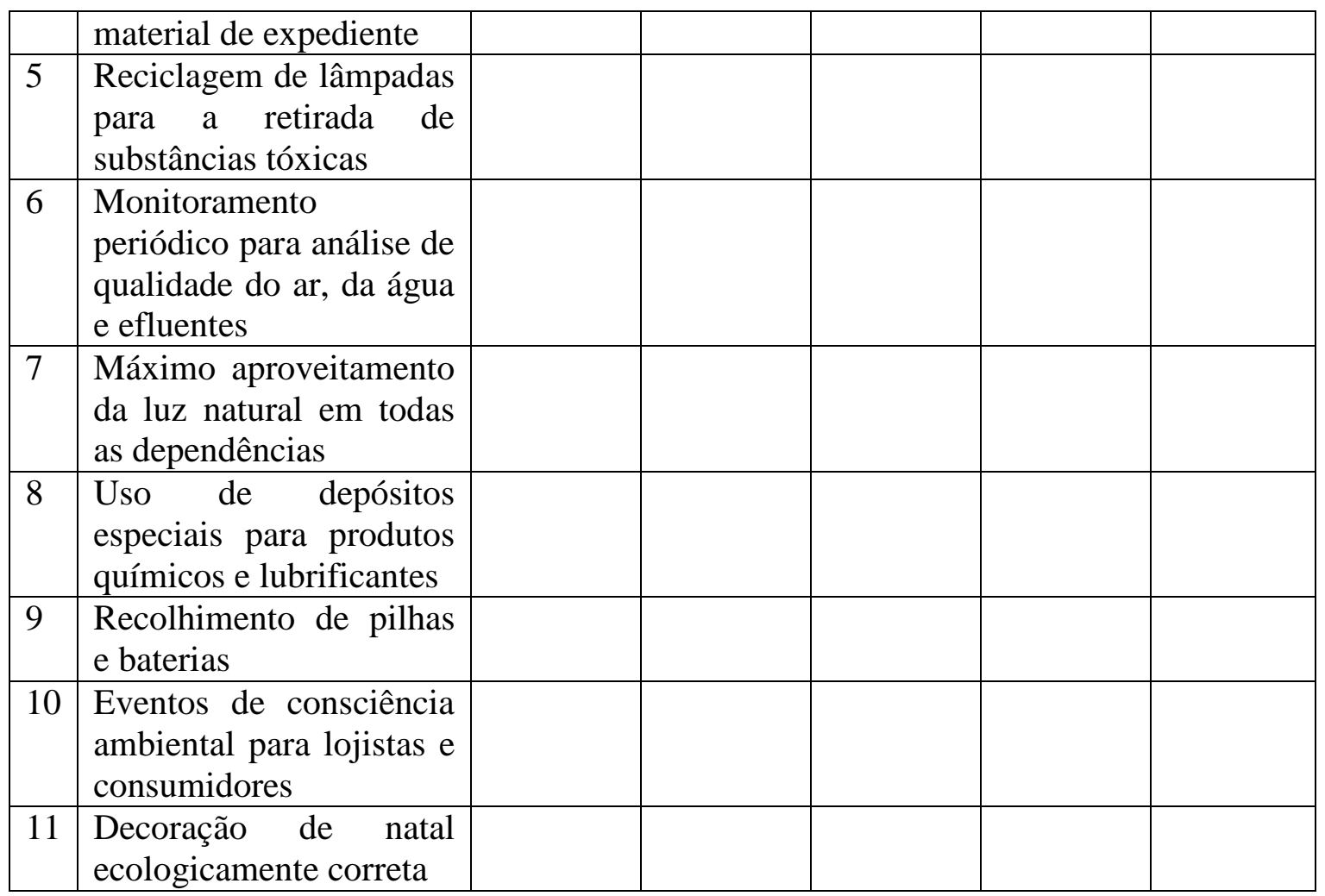

5) Dos programas listados na questão anterior, o(a) senhor(a) considera algum como sendo impactante em suas atividades de trabalho? Marque um $\mathrm{X}$ ao lado do programa que considerar impactante.

\begin{tabular}{|c|c|}
\hline & Programas ambientais \\
\hline 1 & $\begin{array}{l}\text { Atuação em conformidade com a legislação e normas } \\
\text { ambientais }\end{array}$ \\
\hline 2 & $\begin{array}{l}\text { Coleta Seletiva de lixo produzido em todas as lojas e } \\
\text { instalações }\end{array}$ \\
\hline 3 & Controle do consumo de água e energia \\
\hline 4 & $\begin{array}{l}\text { Utilização de papel reciclável em todo o material de } \\
\text { expediente }\end{array}$ \\
\hline 5 & $\begin{array}{l}\text { Reciclagem de lâmpadas para a retirada de substâncias } \\
\text { tóxicas }\end{array}$ \\
\hline 6 & $\begin{array}{l}\text { Monitoramento periódico para análise de qualidade do ar, } \\
\text { da água e efluentes }\end{array}$ \\
\hline 7 & $\begin{array}{l}\text { Máximo aproveitamento da luz natural em todas as } \\
\text { dependências }\end{array}$ \\
\hline 8 & $\begin{array}{l}\text { Uso de depósitos especiais para produtos químicos e } \\
\text { lubrificantes }\end{array}$ \\
\hline 9 & Recolhimento de pilhas e baterias \\
\hline 10 & $\begin{array}{l}\text { Eventos de consciência ambiental para lojistas e } \\
\text { consumidores }\end{array}$ \\
\hline 11 & Decoração de natal ecologicamente correta \\
\hline
\end{tabular}

6) Como o(a) senhor(a) avaliaria a comunicação realizada pelo shopping acerca dos programas ambientais realizados?
( ) Ineficiente
( ) Muito eficiente 
( ) Pouco eficiente

( ) Extremamente eficiente

( ) Eficiente

7) $\mathrm{O}$ (a) senhor(a) teria alguma sugestão de programa ambiental que o shopping poderia vir a realizar?

8) Há quanto tempo o(a) senhor(a) trabalha no shopping?
( ) 1 a 3 meses
( ) 1 ano a 2 anos
( ) 4 a 7 meses
( ) Mais de 2 anos
( ) 8 a 11 meses

9) Idade:

( ) 18 a 25 anos
( ) 26 a 30 anos
( ) 31 a 35 anos

( ) 36 a 40 anos

( ) 41 a 45 anos

( ) Acima de 45 anos

10) Gênero:
( ) Masculino
( ) Feminino

11) Grau de escolaridade:

$\begin{array}{ll}\text { ( ) Ensino Fundamental } & \text { ( ) Ensino Superior } \\ \text { ( ) Ensino Médio } & \text { ( ) Pós-graduação }\end{array}$

\section{Apêndice B: Questionário - Gestores Administrativos}

Prezado entrevistado (a),

Este questionário faz parte de uma pesquisa sobre as políticas ambientais de empresas atuantes no setor de shopping centers. As informações obtidas serão utilizadas em uma monografia de graduação do curso de administração de empresas da Universidade de Brasília - UnB.

O questionário levará aproximadamente 7 minutos do seu tempo. Não há respostas certas ou erradas. Suas informações permanecerão em sigilo e não permitirão sua identificação individual. Por favor, leia atentamente as questões até o final e responda com cuidado. Desde já, obrigado pela colaboração.

1) Qual é a área em que o(a) senhor(a) trabalha?

2) Há quanto tempo o(a) senhor(a) trabalha no shopping?
( ) 1 a 3 meses
( ) 4 a 7 meses
( ) 1 ano a 2 anos
( ) 8 a 11 meses
( ) Mais de 2 anos

3) Como o senhor(a) classificaria o seu grau de conhecimento acerca do tema gestão ambiental? 
( ) Não conheço

( ) Não conheço muito bem

( ) Conheço
( ) Conheço bem

( ) Conheço muito bem

4) O senhor(a) já fez algum treinamento sobre gestão ambiental? Se sim, qual foi a empresa pelo qual o treinamento foi realizado?

( ) Não

( ) Sim. Qual?

5) Qual o grau de importância que o senhor(a) atribui a ações ambientais realizadas por empresas atuantes no setor de shopping centers como forma de obtenção de vantagem competitiva?
( ) Sem importância
( ) Muito importante
( ) Pouco importante
( ) Extremamente importante
( ) Importante

6) Existem metas específicas para a sua área acerca das ações ambientais realizadas pelo shopping?
( ) Não
( ) $\operatorname{Sim}$

7) Dos programas realizados pelo shopping e listados abaixo, o(a) senhor(a) considera algum como sendo impactante nas atividades de trabalho realizada pela sua área? Marque um X ao lado do programa que considerar impactante.

\begin{tabular}{|c|c|}
\hline & Programas ambientais \\
\hline 1 & $\begin{array}{l}\text { Atuação em conformidade com a legislação e normas } \\
\text { ambientais }\end{array}$ \\
\hline 2 & $\begin{array}{l}\text { Coleta Seletiva de lixo produzido em todas as lojas e } \\
\text { instalações }\end{array}$ \\
\hline 3 & Controle do consumo de água e energia \\
\hline 4 & $\begin{array}{l}\text { Utilização de papel reciclável em todo o material de } \\
\text { expediente }\end{array}$ \\
\hline 5 & $\begin{array}{l}\text { Reciclagem de lâmpadas para a retirada de substâncias } \\
\text { tóxicas }\end{array}$ \\
\hline 6 & $\begin{array}{l}\text { Monitoramento periódico para análise de qualidade do ar, } \\
\text { da água e efluentes }\end{array}$ \\
\hline 7 & $\begin{array}{l}\text { Máximo aproveitamento da luz natural em todas as } \\
\text { dependências }\end{array}$ \\
\hline 8 & $\begin{array}{l}\text { Uso de depósitos especiais para produtos químicos e } \\
\text { lubrificantes }\end{array}$ \\
\hline 9 & Recolhimento de pilhas e baterias \\
\hline 10 & $\begin{array}{l}\text { Eventos de consciência ambiental para lojistas e } \\
\text { consumidores }\end{array}$ \\
\hline 11 & Decoração de natal ecologicamente correta \\
\hline
\end{tabular}

8) Dos benefícios listados abaixo, qual(is) o(a) senhor(a) considera que o shopping vem alcançando com suas ações ambientais? Marque quantas alternativas desejar.

\begin{tabular}{|l|l|l|}
\hline 1 & Melhor adequação aos padrões ambientais & \\
\hline 2 & Melhoria da imagem institucional & \\
\hline 3 & Renovação no portfólio de serviços & \\
\hline
\end{tabular}




\begin{tabular}{|l|l|l|}
\hline 4 & Aumento da produtividade & \\
\hline 5 & $\begin{array}{l}\text { Maior comprometimento por parte da força de trabalho e } \\
\text { melhor relacionamento com os empregados }\end{array}$ & $\begin{array}{l}\text { Melhores relações com órgãos públicos, comunidade e } \\
\text { grupos ambientalistas }\end{array}$ \\
\hline 7 & Acesso garantido a novos mercados & \\
\hline 8 & Economia de custos & \\
\hline 9 & Incremento de receita & \\
\hline
\end{tabular}

9) Qual ou quais alternativas abaixo citam os stakeholders que influenciaram a administração do shopping a adotar políticas ambientais? Marque quantas alternativas desejar.
( ) Governo
( ) Mídia
( ) Clientes do shopping
( ) Funcionários
( ) Lojistas
( ) Grupo SONAE
( ) Outro(s):

10) Qual é o grau de influência do grupo SONAE na definição de metas ambientais para o shopping?
( ) Nenhum
( ) Médio
( ) Baixo
( ) Alto

11) Haveria algum programa social que seja beneficiado pelos impactos dos programas ambientais realizados pelo shopping?
( ) Não
( ) Sim. Qual?

12) Idade:
( ) 18 a 25 anos
( ) 36 a 40 anos
( ) 26 a 30 anos
( ) 41 a 45 anos
( ) 31 a 35 anos
( ) Acima de 45 anos

13) Gênero:
( ) Masculino
( ) Feminino

14) Grau de escolaridade:
( ) Ensino Fundamental
( ) Ensino Superior
( ) Ensino Médio
( ) Pós-graduação

\section{Apêndice C: Roteiro - Funcionários de apoio}

- Observar e relatar como se dá o processo de coleta do lixo, verificando fatores como:

- Coleta;

- Separação.

- Analisar se os funcionários possuem algum procedimento de atendimento e orientação aos clientes do shopping; 
- Agindo como um cliente do shopping, perguntar aos funcionários de maneira informal, questões relativas ao descarte de lixo. Procurando abordar funcionários de limpeza do shopping, segurança e limpeza da praça de alimentação;

OBS: Analisar a estrutura física do shopping, verificando se há avisos de orientação aos clientes, como o lugar certo que eles devem depositar determinados tipos de objetos, nas lixeiras seletivas, assim como avisos para a redução do uso racional de recursos (água, papel, etc.) nos banheiros.

Verificar se existem aparelhos que auxiliem no uso eficiente de recurso como os temporizadores nas torneiras, iluminação, etc.

Tendo como objetivo final a cooperação dos próprios usuários para um bom andamento das ações planejadas. 